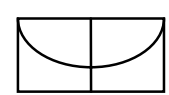

UNIVERSIDADE DE BRASÍLIA

Centro de Excelência em Turismo

\title{
INVENTÁRIO E DIAGNÓSTICO ECOTURÍSTICO RPPN SERINGAL TRIUNFO
}

\author{
Paulo Sergio Colares Gonsalves
}

Sérgio Salazar Salvati

Monografia apresentada ao Centro de Excelência em Turismo da Universidadde de Brasília como requisito parcial para obtenção do certificado de Especialista em Ecoturismo.

Brasília, DF, 14 de setembro de 2004. 
UNIVERSIDADE DE BRASÍLIA

Centro de Excelência em Turismo

Curso de Especialização em Ecoturismo

\title{
INVENTÁRIO E DIAGNÓSTICO ECOTURÍSTICO RPPN SERINGAL TRIUNFO
}

\author{
Paulo Sergio Colares Gonsalves
}

Banca Examinadora

Sérgio Salazar Salvati, Mestre em Ecoturismo

Orientador

Lucila Maria Egydio, Especialista em Ecoturismo

Membro da Banca

Brasília, DF, 14 de setembro de 2004. 
Gonsalves, Paulo S. C.

Inventário e Diagnóstico Ecoturístico RPPN Seringal Triunfo /

Paulo Sergio Colares Gonsalves.

vi, 62 f. : il.

Monografia (Especialização em Ecoturismo) - Universidade de Brasília. Centro de Excelência em Turismo. Brasília, 2004.

Área de concentração: Ecoturismo

Orientador: Sérgio Salazar Salvati.

1. Ecoturismo 2. Meio-Ambiente 3. RPPN. - Monografia. 


\section{INVENTÁRIO E DIAGNÓSTICO ECOTURÍSTICO RPPN SERINGAL TRIUNFO}

Comissão Avaliadora

\begin{tabular}{c}
\hline $\begin{array}{c}\text { Sérgio Salazar Salvati } \\
\text { Orientador }\end{array}$ \\
\hline$\overline{\text { Membro Comissão }}$ \\
\hline
\end{tabular}

Membro Comissão

Brasília, DF, 14 de setembro de 2004. 


\section{DEDICATÓRIA}

Dedico este trabalho à meus pais Elfredo Felix e Maria Darcy que me conduzem pela trilha da vida. Dedico também aos meus irmãos, suas esposas e filhos, George Ernesto, José Elfredo, Luís Edmundo, Carlos Roberto e Ana Claudia , à minha filha Amana e sua mãe Kenia, à minha esposa Kalu e à todos os amigos e amigas que foram pacientes, acreditaram no projeto e serão sempre parceiros da Reserva. 


\section{AGRADECIMENTOS}

Agradeço a Deus pela generosidade das respostas no tempo certo e aos meus orientadores que foram mestres nos momentos vitais.

Muito obrigado! 
EPÍGRAFE

“ Quer ser universal? Cante sua aldeia.” Tolstoi 


\section{RESUMO}

O Ecoturismo tem se destacado como importante instrumento de conservação ambiental e de desenvolvimento econômico e social em diversas regiões do Brasil e do mundo. Dessa forma, as áreas protegidas por legislação ambiental têm importante papel na inclusão social e no desenvolvimento das atividades desse fenômeno social.

O objetivo desse trabalho é elaborar uma proposta de uso ecoturístico para a Reserva Particular do Patrimônio Natural Seringal Triunfo, indicando os elementos que caracterizam o potencial ecoturístico e propondo possíveis roteiros. Assim, o que se pretende com este estudo específico é viabilizar o desenvolvimento do ecoturismo na RPPN como uma das bases para o desenvolvimento sustentável da região.

Para tanto foi realizado um diagnóstico, através de levantamento de dados e observações in loco, onde foi proposta uma estratégia de uso para a reserva estabelecendo diretrizes. A saída a campo e as visitas aconteceram durante 10 dias do mês de dezembro de 2003, onde foram utilizados formulários, mapas e fotografias que ilustraram a grandiosidade da Reserva. A proposta apresentada seguiu dentro dos princípios de sustentabilidade definidos no trabalho e através da utilização de uma metodologia orientada em dois autores, Boo (1994) e WWF-Brasil (2003) que trabalharam especificamente com a questão do planejamento responsável, apoio e manejo de áreas protegidas.

A RPPN está localizada no Amapá, que é hoje o Estado com maior área de cobertura vegetal nativa preservada do Brasil, protegidas em um grande número de Unidades de Conservação e Reservas Indígenas: são 7.914.662 hectares ou 55,17\% do território. Baseado nos dados coletados, contato com as comunidades vizinhas e reconhecimento físico da área da Reserva, percebe-se que a possibilidade de implantação do Ecoturismo naquela região está fortemente voltada aos aspectos histórico, social, natural e cultural do Estado.

A pesquisa propõe uma estratégia de uso responsável para a Reserva Seringal Triunfo e conclui que é nítido o potencial e a viabilidade de uma atividade ecoturística sustentável na RPPN, e que esta, ainda que sem os recursos financeiros para realizar um Plano de Manejo, tem cumprido seu papel na conservação do meio ambiente e que o ecoturismo tem se mostrado um importante caminho para o desenvolvimento social e econômico daquela região. 
ABSTRACT 


$\begin{array}{ll}\text { SUMÁRIO } & \\ \text { INTRODUÇÃO } & 01 \\ \text { 1 - BASE TEÓRICA } & 02 \\ \text { 1.1 - ECOTURISMO } & 02 \\ \text { 1.2 - UNIDADES DE CONSERVAÇÃO } & 05 \\ \text { 1.3 - RESERVA PARTICULAR DO PATRIMÔNIO NATURAL } & 08 \\ \text { 2 - METODOLOGIA E DADOS } & 10 \\ \text { 2.1 - METODOLOGIA } & 10 \\ 2.2 \text { - SERINGAL TRIUNFO } & 12 \\ \text { I - Histórico } & 12 \\ \text { II - Caracterização do Meio } & 12 \\ \text { a) Meio Físico } & 12 \\ \text { I - Clima e Classificação Climática } & 12 \\ \text { II - Temperatura } & 13 \\ \text { III - Pluviometria } & 13 \\ \text { VI - Umidade Relativa } & 14 \\ \text { V - Solos } & 14 \\ \text { VI - Hidrografia } & 14 \\ \text { VII - Topografia } & 14 \\ \text { b) Meio Biótico } & 14 \\ \text { I - Flora } & 14 \\ \text { II - Fauna } & 16 \\ \text { III - Zoneamento e Plano de Proteção da Unidade } & 17 \\ \text { IV - Capacidade de Carga } & 18\end{array}$


3 - INVENTÁRIO 19

$\begin{array}{ll}3.1 \text { - ATRATIVOS DO ESTADO DO AMAPÁ } & 19\end{array}$

3.2 - ATRATIVOS E INFRA-ESTRUTURA DA RESERVA 21

3.3 - LOCALIZAÇÃO E ACESSO 24

3.4 - ORGANIZAÇÕES GOVERNAMENTAIS E NÃO-GOVERNAMENTAIS 25

3.5 - HOSPEDAGEM, RESTAURANTES E AGÊNCIAS 26

3.6 - PONTOS POSITIVOS E NEGATIVOS 27

4 - DIAGNÓSTICO ECOTURÍSTICO 28

4.1 - AVALIAÇÃO DE DEMANDA 28

4.2 - PARCERIAS LOCAIS 29

5 - RECOMENDAÇÕES PARA A IMPLANTAÇÃO DO ECOTURISMO 31

5.1 - PRODUTOS E ROTEIROS 31

5.2 - INFRA-ESTRUTURA NECESSÁRIA 34

5.3 - CRONOGRAMA DE IMPLANTAÇÃO 35

5.4 - RESULTADOS E DISCUSSÃO 36

6 - CONCLUSÃO

7 - BIBLIOGRAFIA 38

8 - ANEXOS $\quad 40$

8.1 - LEGISLAÇÃO 40

8.2 - MAPAS 44

8.3 - FOTOGRAFIAS $\quad 50$

9 - APÊNDICES 56

9.1 - FORMULÁRIOS 56

9.2 - TÍTULO DE RECONHECIMENTO IBAMA/MMA 61 


\section{LISTA DE ILUSTRACÕES}

Tabela 1. Estimativa de Mercado $\quad 28$

Mapa 1. Unidades de Conservação do Amapá 44

Mapa 2. BR 156 Ferreira Gomes $\quad 45$

Mapa 3. RPPN Seringal Triunfo 46

Mapa 4. Detalhe Fazenda e RPPN 47

Mapa 5. Mapa de Fotografias $\quad 48$

Figura 1. Guarita de Entrada pela Eletronorte $\quad 49$

Figura 2. Lago da Represa do Paredão e RPPN

Figura 3. Represa do Paredão e Corredeiras

Figura 4. Caminho até a sede da Fazenda 50

Figura 5. Mancha de cerrado na Fazenda

Figura 6. O tamanho médio das árvores da propriedade

Figura 7. Vista aérea da Sede da Fazenda

51

Figura 8. Vista externa da Sede da Fazenda

Figura 9. Vista interna da Sede da Fazenda

Figura 10. Área alagada na construção da Represa $\quad 52$

Figura 11. Área alagada na construção da Represa

Figura 12. Área alagada na construção da Represa

Figura 13. Área alagada na construção da Represa e RPPN ao fundo 53

Figura 14. Açaí

Figura 15. Buriti

Figura 16. Prainha

Figura 17. Corredeiras na Prainha

Figura 18. Igarapé Traíra

Todas as fotografias (2000 a 2003) e mapas (2004) desta lista de ilustrações foram produzidas pelo autor da monografia, com a excessão da figura número 07 (vista aérea da sede da fazenda), gentilmente cedida pelo piloto Jorge Colares Júnior. Os mapas 1 e 2 foram produzidos a partir do Guia de Estradas 2003, Quatro Rodas, Editora Abril; e os mapas 3, 4 e 5 a partir da Planta da Situação e Localização do Imóvel, anexada ao Projeto de Criação da RPPN. 


\section{INTRODUÇÃO}

Segundo dados da FAO, a área desmatada em florestas tropicais subiu de 11,4 milhões em 1980 para 17 milhões em 1990, representando quase 50\% de aumento. Nos últimos anos vem crescendo as pressões ambientais sobre a Amazônia e hoje boa parte da população mundial volta seus olhos à devastação da Floresta. Organizações de todo o planeta vêm fazendo pressões contra a exploração da maior floresta tropical do mundo.

Para Fenell (2002) o simples fato do local ser identificado como área protegida e consequentemente, incluído no conceito de local de relevante beleza natural e de elevada preservação, já empresta ao lugar caráter de atrativo, gerando demanda pelo seu uso recreativo.

No entanto, a atividade do Ecoturismo deve abranger, com sua conceituação, a dimensão do conhecimento da natureza, a experiência educacional interpretativa, a valorização das culturas tradicionais locais e a promoção do desenvolvimento sustentável. Assim, as terras privadas dedicadas ao ecoturismo ou à educação ambiental, podem representar parte importante das estratágias globais de conservação para os países em desenvolvimento.

A área estabelecida para esse estudo foi a propriedade Seringal Triunfo, situada em Ferreira Gomes, Amapá (150 km da capital Macapá). Essa área está decretada como uma Reserva Particular do Patrimônio Natural desde $1^{\circ}$ de julho de 1998 e já recebe visitação não-ordenada desde tempos anteriores a sua criação. Assim, o objetivo desse trabalho é elaborar uma proposta de uso ecoturístico para a RPPN Seringal Triunfo, indicando os elementos que caracterizam o potencial ecoturístico e propondo possíveis roteiros. Dessa maneira, o que se pretende com este estudo específico é estabelecer diretrizes, recomendações e um plano de ação para viabilizar e implementar o desenvolvimento o ecoturismo na RPPN como uma das bases para o desenvolvimento sustentável da região.

O estudo da Reserva inicia-se com a revisão o material existente sobre os temas Ecoturismo, Unidades de Conservação e RPPN, para em seguida descrever a metodologia utilizada na pesquisa e os dados coletados sobre a propriedade. No capítulos finais apresenta-se os diversos resultados encontrados na pesquisa sobre o Amapá e sobre a RPPN Seringal Triunfo, para então fazer a análise da pesquisa sob a luz do Ecoturismo, propondo uma estratégia de implantação de infra-estrutura e atividades na Reserva, e estimulando o empreendedorismo do proprietário. 


\section{1 - BASE TEÓRICA}

\section{1 - ECOTURISMO}

A indústria do turismo é, na atualidade, a atividade que apresenta os mais elevados índices de crescimento no contexto econômico internacional. Situando-se entre os maiores contribuintes do Produto Interno Bruto Mundial, movimenta cerca de US\$ 3,5 trilhões anualmente e, apenas na última década, expandiu sua atividade em 57\% (EMBRATUR, 1994).

Dessa forma, o ecoturismo é o segmento do turismo que apresenta o maior crescimento ao longo dos anos. Apesar da ausência de estatísticas oficiais relativas à dimensão deste mercado, o seu crescimento é estimado em cerca de $20 \%$ ao ano, já representando $10 \%$ das atividades turísticas totais (EMBRATUR, 1994).

Nos últimos anos, vem aumentando a procura por este tipo de turismo,bem como o número de publicações, de programas de TV, de órgãos ligados ao assunto, etc. Estima-se que mais de meio milhão de pessoas no Brasil pratiquem o ecoturismo, que deve empregar cerca de 30 mil pessoas, através de, no mínimo 5 mil empresas e instituições privadas.

Existem diversas hipóteses para tentar explicar o por quê de as pessoas estarem buscando esse tipo de atividade. As mais comuns são a preocupação com o meio ambiente, maior conscientização ecológica e uma maneira de fugir da rotina e do estresse dos grandes centros urbanos.

Porém, a inexistência da definição globalmente aceita para Ecoturismo, com o conseqüente enquadramento das atividades que devem ser consideradas neste segmento, vem dificultando a existência de estudos cientificamente fundamentados e conclusivos sobre a matéria (EMBRATUR, 1994), fazendo com que as estatísticas sobre o Ecoturismo sejam divergentes.

Mesmo assim, o Ecoturismo tem se inserido, cada vez mais, nas políticas de promoção do desenvolvimento econômico e social, configurando-se, no momento, como importante alternativa de desenvolvimento econômico sustentável. O adequado aproveitamento dos variados ecossistemas existentes, e ainda pouco explorados, pode propiciar a abertura de novas alternativas econômicas e a consequente melhoria das condiçnoes de vida das populaçnoes envolvidas, além de reduzir os impactos negativos causados pelo turismo tradicional (EMBRATUR, 1994).

A Costa Rica, por exemplo, país considerado número um em Ecoturismo por trinta e cinco dos mais importantes editores e jornalistas americanos especializados, possui cerca de $25 \%$ de seu território constituído por áreas protegidas - públicas ou privadas, sendo que $75 \%$ dos turistas visitam pelo menos um parque nacional (MOURÃO, 2001).

Atualmente existem vários conceitos para Ecoturismo. Não raro cada autor acaba elaborando sua própria definição. Para Boo (1994), o Ecoturismo emergiu da convergência entre duas tendências mundiais: a conservação e a industria de viagem. Por parte da conservação, existe hoje a tendência de integração entre conservação e desenvolvimento econômico como meio de se atingir um desenvolvimento sustentável. Nesse sentido, o Ecoturismo é uma forma de gerar recursos a 
partir da 'venda' de destinos naturais ao mesmo tempo em que os conserva. No âmbito da indústria de viagem, está havendo a mudança de atitude e de valores: o turismo tem se orientado cada vez mais para a natureza. Grande parte dessa mudança é devida ao interesse mundial pelo meio ambiente e fatores a ele relacionados, como animais em extinção, desmatamento, etc.

Fenell (2002) no seu ensaio de uma análise histórica do conceito de Ecoturismo e da identificação das principais características e princípios do termo fez levantamento de vários autores. Para ele a base conceitual do termo remonta a década de sessenta, quando aparece no trabalho de Hetzer $(1965)^{1}$, no qual ele identificava quatro pilares para o turismo mais responsável: impacto ambiental mínimo; mínimo impacto e máximo respeito às culturas anfitriãs; benefícios para a comunidade anfitriã e satisfação do turista (FENNELL, 2002).

No entanto, diante da diversidade de autores e de conceitos sobre o Ecoturismo e à luz de uma vasta revisão literária, Fennell (2002) criou sua própria definição de Ecoturismo, na tentativa de abranger os aspectos mais importantes do fenômeno como sendo "uma forma sustentável de turismo baseado nos recursos naturais, que focaliza principalmente a experiência e o aprendizado sobre a natureza; é gerido eticamente para manter um baixo impacto, é não-predatório e localmente orientado (controle, benefícios e escala). Ocorre tipicamente em áreas naturais, e deve contribuir para a conservação ou preservação destas.” (FENNELL, 2002).

Para a Embratur (1994), o conceito nacional de Ecoturismo pode ser definido como "um segmento da atividade turística que utiliza de forma sustentável o patrimônio natural e cultural, incentiva sua conservação e busca a formação de uma consciência ambientalista através da interpretação do ambiente, promovendo o bem estar das populações envolvidas.”

Nesse sentido, segundo a Organização Não-Governamental WWF (2001), para que uma atividade se classifique como Ecoturismo, são necessárias quatro condições básicas² :

- valorização das comunidades locais: o turismo deve não só respeitar e valorizar as culturas locais, seus conhecimentos e experiências, como também deve buscar benefícios e promover oportunidades de desenvolvimento para a comunidade local, e ainda o envolvimento econômico efetivo das comunidades locais, de forma a melhorar sua qualidade de vida;

- desenvolvimento sustentável: para ser compatível com os conceitos do desenvolvimento sustentável, o Ecoturismo deve ser planejado, gerido e empreendido de modo a evitar danos ao meio, sendo ambientalmente sustentável, economicamente viável e socialmente eqüitativo. O caminho ideal para o ecoturismo é o que se chama desenvolvimento sustentável. Este conceito propõe a integração da comunidade local com atividades que possam promover a conservação e o uso sustentável dos recursos naturais e culturais. Segundo Seabra (2001), é o desenvolvimento capaz de garantir as necessidades do presente sem comprometer a capacidade das gerações futuras de atender a suas necessidades;

\footnotetext{
${ }^{1}$ HETZER, N. D. Environment, tourism, culture. LINKS, 1965. reeditado em Ecosphere, 1970. 1(2): 1-3.

${ }^{2}$ Adaptado pelo autor a partir de WWF (2001).
} 
- conservação: o manejo do turismo deve sempre primar pelo respeito às condições naturais, a conservação do meio ambiente e o uso sustentável dos recursos naturais, que são essenciais para a manutenção de um ambiente sadio;

- promoção da consciência ambiental: através da interação educacional com o meio ambiente garantia de que o turista incorpore para a sua vida o que aprende em sua visita, gerando consciência para a preservação da natureza e dos patrimônios histórico, cultural e étnico, além de reforçar atitudes, valores e medidas que favoreçam a conservação e o desenvolvimento sustentável para todos.

Contudo, a oferta dos destinos ecoturísticos depende não só da existência de áreas de elevado valor ecológico e cultural, mas também da maneira como essas áreas são geridas, da existência de infra-estruturas adequadas e da disponibilidade de recursos humanos capacitados. Fatores que nem sempre estão presentes nas unidades de conservação federais (EMBRATUR, 1994). 


\section{2 - UNIDADES DE CONSERVAÇÃO}

Os movimentos mais abrangentes para a proteção de áreas naturais como espaços de uso público parecem só ter surgido após a Revolução Industrial, devido a grande pressão e a rápida transformação que a paisagem vinha sofrendo, em decorrência da expansão da demanda por matéria prima. E também por causa do surgimento de uma classe crescente de pessoas em rotinas estressantes de trabalho em fábricas, que necessitavam de espaços para a recreação ao ar livre (MILANO, 2000).

No mundo inteiro, aproximadamente 750 milhões de hectares de ecossistemas terrestres e marinhos são objeto de alguma forma de proteção, o que totaliza cerca de 1,5\% da superfície da Terra, ou, 5,1\% da extensão territorial dos países (WRI/UICN/PNUMA, 192 citado por MMA, 2003b).

Em contrapartida, milhões de hectares de florestas são derrubadas anualmente, o que gera grande pressão nas Unidades de Conservação já estabelecidas que muitas vezes tornam-se ilhas de vegetação nativa, privadas de fluxo gênico (pólem e sementes) de plantas e animais que tem seu trânsito confinado a esses remanescentes.

Em 1992, na Conferência das Nações Unidas sobre o Meio Ambiente e Desenvolvimento, a Rio92, foi elaborada a Agenda 21. Este documento, entre outros pontos, ressalta a importância de integrar estratégias para a conservação da diversidade biológica e o uso sustentável dos recursos naturais às estratégias dos planos nacionais de desenvolvimento. O cuidado com o patrimônio natural, a sua exploração racional com vistas à sua conservação e a preservação dos processosnaturais e da biodiversidade, passaram a ser considerados fundamentais dentro de um novo paradigma: o do desenvolvimento sustentável. Assim, a partir desse momento, as áreas protegidas estavam inseridas no processo de desenvolvimento sustentável.

Com o passar do tempo, as áreas protegidas se consolidaram como uma das formas mais eficientes de garantir a preservação de amostras significativas dos ecossistemas naturais, de conservação da biodiversidade e de manutenção dos processos naturais vitais, frente ao irrefreável avanço no processo de desenvolvimento (EMBRATUR, 1994).

No Brasil, a Lei $n^{0}$ 9.985, promulgada no ano de 2000, após quase oito anos de tramitação no Congresso Nacional, consolidou as legislações anteriores (como os Códigos Florestais de 1934 e 1965 por exemplo) no Sistema Nacional de Unidades de Conservação da Natureza (SNUC), classificando as UCs em dois grupos: Unidades de Proteção Integral e Unidades de Uso Sustentável. Nas primeiras, está totalmente restringida a exploração ou o aproveitamento dos recursos naturais, admitindo-se apenas o aproveitamento indireto dos seus benefícios. São identificadas também como Unidades de Uso Indireto e se constituem nos Parques Nacionais, Reservas Biológicas, Estações Ecológicas, Monumentos Naturais e Refúgios de Vida Silvestre. As Unidades de Uso Sustentável admitem a exploração e o aproveitamento econômico direto dos recursos de forma planejada e regulamentada. São identificadas também como Unidades de Uso Direto e são constituídas pelas Áreas de Proteção Ambiental, Áreas de Relevente Interesse Ecológico, Florestas Nacionais, Reservas Extrativistas, Reservas de Fauna, Reservas de Desenvolvimento Sustentável e Reserva Particular do Patrimônio Natural. Cada uma destas 
categorias tem objetivos de manejo diferenciados, visando cobrir a maior gama de situações, para a garantia da conservação dos recursos naturais (IBAMA, 1997).

O Brasil está atualmente, junto com a Colômbia, o México e a Indonésia, entre os quatro países mais ricos na diversidade de fauna e flora. No Brasil que é o campeão em número total de organismos, vivem cerca de três mil espécies de vertebrados terrestres e três mil de peixes de água doce. Aqui, são encontrados também 55 mil espécies de plantas com flores, o que equivale a $22 \%$ de todas as plantas com flores existentes no planeta. Há ainda 517 espécies de anfíbios (sapos, rãs, etc.), o que representa $12 \%$ das espécies do mundo, 77 espécies de primatas (macacos) - 26\% do total de espécies existentes na Terra, e mais 17\% das aves do mundo. Grande parte da diversidade estimada de insetos - algo em torno de 10 a 15 milhões de espécies, a maioria ainda desconhecida - encontra-se em território brasileiro. O Brasil ocupa segundo lugar em número de mamíferos (524 espécies), a terceira posição em número de pássaros (1.622 espécies) e em número de palmeiras (387 espécies) e quarto lugar em neumero de répteis (468 espécies) (IBAMA/FUNBIO, 1999).

Ou seja, em termos de biodiversidade, o Brasil apresenta-se com o título de detentor da maior diversidade biológica do planeta, contando com pelo menos 10 a $20 \%$ do número total de espécies do mundo (EMBRATUR, 1994).

Segundo o IBAMA (MMA, 2003c), o país dispõe, hoje, de um quadro extenso de unidades de conservação. As 248 Unidades de Conservação Federais de uso direto e indireto (sem adicionar as RPPNs) somam 53.217.332,87 hectares ${ }^{3}$ ou 6,23\% do território continental brasileiro.

Como Unidades Federais de Proteção Integral o Brasil possui 52 Parques Nacionais, 29 Estações Ecológicas, 25 Reservas Biológicas, 2 Resrvas Ecológicas ${ }^{4}$ e 1 (um) Refúgio de Vida Silvestre, num total de 109 unidades de Proteção Integral, ou seja, 2,77\% do território nacional continental.

Como Unidades Federais de Uso Sustentável, existem atualmente: 29 Áreas de Proteção Ambiental, 63 Florestas Nacionais, 30 Reservas Extrativistas e 17 Áreas de Relevante Interesse Ecológico ${ }^{5}$ num total de 139 unidades, o que representa 3,52\% da área continental do Brasil (MMA, 2003b).

As Reservas Particulares do Patrimônio Natural somam mais 390 Unidades de Conservação, totalizando 638 Unidades de Conservação Federais ou 53.762.159,89 hectares (MMA, 2003a).

A soma dessas categorias totaliza 6,29\% do território nacional. Mesmo as sobreposições tendo sido processadas e excluídas nessa soma, esse valor é um pouco superestimado, principalmente devido ao fato de que as Áreas de Proteção Ambiental, muitas vezes, não se constituem em

\footnotetext{
${ }^{3}$ Os valores referentes as áreas das UCs foram obtidos dos decretos de criação e revisão de limites, ou por meio de cálculo através de técnicas de geoprocessamento. A estatística foi realizada pela Diretoria de Ecossistemas do IBAMA, atualizada em 03/01/2003.

${ }^{4}$ Eram cinco Reservas Ecológicas, contudo duas (Raso da Catarina/BA e Jutaí-Solimões/AM) mudaram para Estação Ecológica e a outra (Juami-Jupurá/AM) foi englobada por uma Estação Ecológica.

${ }^{5}$ Eram 19 áreas, mas duas (Ilhas do Pinheiro e Pinheirinhos/PR e Mirici/AL) foram englobadas por outras UCs.
} 
instrumentos capazes de garantir a conservação plena dos recursos, funcionando muito mais como uma tentativa de ordenamento territorial e de uso do solo, grande parte das vezes já previstos na legislação vigente. Mesmo assim, esse percentual reflete um esforço considerável de conservação in situ ${ }^{6}$ da diversidade biológica (MMA, 2003a).

Quanto à representatividade da proteção ambiental por biomas, a distribuição percentual de áreas de UCs federais, sem contar com as RPPNs, é a seguinte: a Amazônia ${ }^{7}$ apresenta 10,97\%, a Mata Atlântica 2,63\%, o Cerrado com 2,52\%, a Caatinga com 2,95\%, o Planalto Sul Brasileiro com 2,15\% e o Pantanal com 0,57\%. O bioma Costeiro possui 13,51\% de sua superfície oficialmente protegida (MMA, 2003b).

Como se pode observar, o total de área protegida por bioma é insuficiente para a conservação da biodiversidade brasileira, visto que, segundo as conclusões do IV Congresso Internacional de Áreas Protegidas, relizado em Caracas, na Venezuela, em 1992, a recomendação é de que haja no mínimo de $10 \%$ das áreas de proteção integral por bioma (MMA, 2003a). Já a comissão Brundtland - a Comissão Mundial de Meio Ambiente e Desenvolvimento - fixou um padrão de $12 \%$ para todos os países em termos de quantidade de território necessário para o estabelecimento de parques e áreas protegidas, acreditando que esse padrão irá garantir um bom grau de proteção para todas as principais regiões fisiográficas da terra (FENNELL, 2002).

Como se pode verificar, dos biomas continentais, apenas a Floresta Amazônica está dentro do padrão ideal, principalmente por ter sido favorecida pela sua grande extensão, sua pouca ocupação e ao poder público ter, de certa forma, se adiantado à ocupação dessa fronteira (MMA, 2003b). Contudo, em muitos casos, as unidades não estão consolidadas nem regularizadas fundiariamente, onde há fazendas desapropriadas mas não regularizadas ou indenizadas aos exproprietários e esta situação causa todo tipo de irregularidades e degradação ambiental nos ecossistemas envolvidos.

\footnotetext{
${ }^{6}$ Conservação in situ: quando o estoque é preservado mediante a proteção do ecossistema onde o organismo encontra seu meio natural. Conservação ex situ: que pode ser parte do organismo - quando é preservado a semente, o sêmem, ou qualquer outro elemento a partir do qual será possível a reprodução do organismo preservado - ou o organismo inteiro - quando uma certa quantidade de organismos ee mantida fora do seu meio natural, em plantações, jardins botiânicos, zoológicos, aquários, prédios ou coleções para cultivo. Das estratégias acima mencionadas, a preservação in situ é a preferida, pois se preserva também os ecossistemas e paisagens, o que resulta no alcance de outros tantos objetivos (MMA, 2003b).

7 A Amazônia possuía 7,6\% do território em Unidades de Conservação. Com a criação do Parque Nacional Montanhas do Tumucumaque, em 2002, no Amapá, esse percentual passou para 11\%.
} 


\section{3 - RESERVA PARTICULAR DO PATRIMÔNIO NATURAL}

No Brasil, além da pequena quantidade do território que está protegido pela Legislação Brasileira, há ainda a pouca representatividade dos ecossistemas. O Programa de Reservas Particulares do Patrimônio Natural veio somar esforços para a proteção de ecossistemas ameaçados.

Através do Decreto Federal no 98.914 de 31 de janeiro de 1990 ficou instituída, sob a gerência do Instituto Brasileiro do Meio Ambiente e dos Recursos Naturais Renováveis - IBAMA, a Reserva Particular do Patrimônio Natural - RPPN, que regulamentou o artigo $6^{\circ}$ do Código Florestal de 1965 - base da legislação sobre reservas particulares.

O Decreto n 1.922/96 (ANEXO 8.1 - pág. 40) que dispõe sobre o reconhecimento de Reservas Particulares do Patrimônio Natural, deu grande estímulo à criação de Reservas Particulares do Patrimônio Natural, incrementando o número de unidades criadas por ano (MMA, 2003).

Os resultados desses doze anos de implantação revelam como as RPPNs podem se tornar um instrumento fundamental para a conservação dos ecossistemas. Entre 1990 e 2002, foram 390 RPPNs reonhecidas pelo IBAMA em instância federal para a conservação de, aproximadamente, 544.827 hectares dos diversos biomas.

Nota-se assim que as Áreas Particulares Protegidas deram um significativo impulso nas iniciativas de conservação do país. As RPPNs representam um importante passo para envolver direta e voluntariamente a sociedade civil brasileira na conservação da biodiversidade. Por intermédio desse mecanismo, a iniciativa privada pode dar a sua contribuição à proteção do meio ambiente e aumentar significativamente a possibilidade de se obter um cenário efetivo de áreas protegidas. O maior exemplo disso pode ser observado no bioma Pantanal, que, por meio dessa iniciativa, conseguiu ter sua área de conservação ambiental, que era de 0,57\% ampliada para 2,14\% do bioma (MMA, 2003a).

As RPPNs, são portanto, áreas de conservação da natureza em propriedades privadas e pertencem ao grupo das UCs de uso sustentável. Elas têm como objetivo básico compatibilizar a conservação da natureza com o uso sustentável de parcela dos seus recursos naturais. A existência de uma RPPN é um ato de vontade do proprietário que decide se quer fazer de sua propriedade, ou de parte dela uma Reserva, sem que isso acarrete perda do direito de propriedade.

O programa de RPPNs foi criado para estimular a preservação de áreas particulares que apresentem paisagens de grande beleza, sejam significativas para a proteção da diversidade ou reuna condições que justifiquem ações de recuperação ambiental, capazes de promover a conservação de ecossistemas frágeis ou ameaçados. 
A RPPN é uma Unidade de Conservação de domínio privado, proteção integral, enquadrada pela lei federal $n^{\circ}$ 9.985/00 (SNUC) de 18 de julho de 2000 como UC de uso sustentável (ANEXO 8.1 - pág. 40). A categoria de uso sustentável concilia conservação da natureza com uso sustentável de parcelas dos seus recursos naturais. O artigo 25 da lei SNUC exclui as RPPN's e APA's (Áreas de Proteção Ambiental) da obrigatoriedade de possuir uma zona de amortecimento. Sendo assim, é uma das categorias de UC's mais susceptíveis a receber impactos de atividades degradantes de áreas vizinhas influindo diretamente no equilíbrio das comunidades ecológicas de uma RPPN.

Atualmente, a câmara técnica de assuntos jurídicos e a câmara técnica de ecossistemas, enviaram uma minuta de decreto para ser analisada em plenário do CONAMA (Conselho Nacional de Meio Ambiente), na qual regulamenta artigos da Lei 9.985/00. Nesta minuta de decreto em seu capítulo III, é regulamentado o "Mosaico de Unidades de Conservação", na qual prevê em seu artigo $9^{\circ}$, que os corredores ecológicos, entre unidades de conservação serão reconhecidos por ato do Ministério de Meio Ambiente. Na verdade o mosaico é constituído de um conjunto de unidades de conservação de categorias diferentes ou não, próximas, justapostas ou sobrepostas, que no conjunto representem um sistema mais significativo de preservação da biodiversidade, desta forma a RPPN poderia ser beneficiada por zona de amortecimentos de UCs vizinhas.

As Reservas Particulares do Patrimônio Natural oferecem condições para a implantação de projetos de ecoturismo, de pesquisa científica, de educação ambiental para despertar a verdadeira consciência ecológica. O ecoturismo, no conceito moderno, é uma fonte inesgotável de novos empregos, nos mais variados ramos de atividade. Assim, as RPPNs situam-se como locais próprios para a prática desta atividade, multiplicando quantitativa e qualitativamente os espaços naturais potenciais para o Ecoturismo, visto se tratar de locais de grande valor ecológico. Além disso, dado ao caráter privado e às dimensões das RPPNs (em geral, bem menores que os Parques Nacionais , por exemplo), fatores como infra-estrutura adequada, recursos humanos qualificados e gestão eficiente para a atividade são viáveis, visto que não passam pelos entraves burocráticos existentes em outras Unidades de Conservação públicas.

No entanto, as queixas dos proprietários de RPPNs são principalmente com relação aos poucos estímulos para sua criação como: falta de regulamentação detalhada; baixa redução do Imposto Territorial Rural, perpetuidade e sem indenização; as limitações ao uso; e o alto custo do plano de manejo (apesar do proprietário ter direito a orientação técnica e científica dos órgãos ambientais segundo o SNUC, esse fato não ocorre na prática). 


\section{2 - METODOLOGIA E DADOS}

\section{1 - METODOLOGIA}

A pesquisa em Turismo é realizada por um conjunto de métodos empíricos e experimentais, envolvendo conhecimentos científico, técnico e prático. Durante o trabalho, foram coletados os dados e feitas as observações in loco a fim de, revelar os aspectos naturais e culturais do Amapá, o que trouxe grande riqueza de informações ao estudo. Além disso, a consulta do Projeto de Criação da RPPN Seringal Triunfo, foi fundamental para o planejamento dos roteiros e da infraestrutura.

A proposta do estudo é apresentar, à partir da discussão dos resultados do inventário, quais produtos ecoturísticos a Reserva pode oferecer e o público-alvo para estes produtos.

O inventário da RPPN Seringal Triunfo foi realizado de 11 a 21 de dezembro de 2003 e contou com, além do autor da monografia, os seguintes participantes na equipe técnica:

- Sra. Mara Raidy, amapaense, cozinheira profissional;

- Sr. Elfredo Távora, paraense, jornalista e proprietário da RPPN;

- Sr. Pedro Manuel, amapaense, caseiro da fazenda e guia mateiro;

- Sr. George Ernesto, amapaense, administrador da fazenda e motorista.

O inventário da Reserva constituiu-se em pesquisa de campo para reconhecimento da área, percepção das comunidades para a atividade turística e identificação das características sócioculturais e ambientais que poderiam se apresentar como atrativos turísticos. Para tanto, foi utilizado o Formulário de Atrativos e o Formulário de Atrativos-Águas (FORMULÁRIOS 1, 2 págs. 58, 61). da WWF-Basil (2003), contidos no apêndice deste estudo, para o levantamento do potencial de cada atrativo turístico.

É interessante destacar, que o autor da monografia visita a propriedade há pelo menos vinte anos, em diversas ocasiões e estações do ano, e que contêm vasto material fotográfico pessoal e familiar sobre os diversos ecossistemas da RPPN.

No estudo, optou-se por não hierarquizar os atrativos turísticos, orientando a proposta para o que a Cúpula de Especialistas em Ecoturismo recomenda ao setor privado: “diversificar suas ofertas desenvolvendo um leque de atividades turísticas e estendendo suas visitas a locais diversos de forma a disseminar o potencial de ecoturismo destas regiões e evitar que um determinado local seja superexplorado e sua sustentabilidade colocada em perigo. Para tanto, as operadoras devem respeitar e contribuir para o estabelecimento de limites de visitas de cada local" (Carta de Quebec, item B-31, Canadá, 2002) ${ }^{8}$.

\footnotetext{
${ }^{8}$ Adaptado pelo autor à partir de Carta de Quebec: Recomendações da Cúpula de Especialistas em Ecoturismo (Canadá, 2002). Documento revisto e aprovado pelo Programa de Meio Ambiente das Nações Unidas e pela Organização Mundial do Turismo.
} 
A coleta de informações e a visita técnica à propriedade revelaram as peculiaridades da Reserva para o Ecoturismo. As atividades realizadas, a logística e os tempos de viagem no Amapá e na Reserva aconteceram de acordo com o seguinte roteiro (dezembro, 2003):

QUINTA-FEIRA (11): Macapá:

- Visita à orla do rio Amazonas, lojas de artesanato e Fortaleza de São José;

- Visita ao Monumento do Marco Zero;

- Visita ao DETUR - Departamento de Turismo do Amapá;

- Visita à APA do Curiaú (uma hora de automóvel).

SEXTA-FEIRA (12): RPPN Seringal Triunfo:

- Viagem pela BR 156 até o Município de Ferreira Gomes (uma hora e meia de automóvel);

- Visita aos órgãos de saúde e segurança pública do município;

- Chegada e reconhecimento da propriedade por mapas;

- Passeio pela mata, observação de aves e vegetação próximo ao Igarapé Traíra;

- Caminhada pelo cerrado.

SÁBADO (13): RPPN Seringal Triunfo:

- Passeio em canoa a remo pelo lago da RPPN com observação de vegetação, pela manhã;

- Passeio em canoa a remo pelo lago da RPPN com observação de aves, pela tarde;

DOMINGO (14): Macapá:

- Caminhada pela propriedade até a prainha e as corredeiras do rio Araguari;

- Viagem de retorno à cidade de Macapá.

SEGUNDA-FEIRA (15): Macapá:

- Dia livre para a equipe.

TERÇA-FEIRA (16): Macapá:

- Consulta sobre a História do Amapá nas bibliotecas públicas de Macapá.

QUARTA-FEIRA (17): Macapá:

- Encontro com chefe do Programa RPPN do IBAMA/AP;

- Visita ao INPA - Instituto Nacional de Pesquisa na Amazônia.

QUINTA-FEIRA (18): Macapá:

- Visita à orla do rio Amazonas, lojas de artesanato e Fortaleza de São José;

- Visita à Associação dos Povos Indígenas do Tumucumaque.

SEXTA-FEIRA (19): Macapá:

- Visita ao Jardim Botânico e ao Zoológico de Macapá (meia hora de automóvel);

- Visita à APA da Fazendinha (quarenta e cinco minutos de automóvel).

SÁBADO (20): Município de Cutias:

- Viagem pela BR 156 até o Município de Ferreira Gomes (uma hora e meia de automóvel);

- Viagem pela AP 010 até o Município de Cutias (uma hora e meia de automóvel 4X4);

- Observação da Pororoca no baixo rio Araguari (a proximidade da lua nova aumenta o volume);

- Pernoite em pensão no Município de Cutias.

DOMINGO (21): Macapá:

- Dia de lua nova;

- Viagem de retorno à cidade de Macapá. 


\section{2 - SERINGAL TRIUNFO}

A escolha da Reserva Particular do Patrimônio Natural Seringal Triunfo como objeto de estudo se deu por três fatores: o conhecimento particular do autor sobre a Reserva; a realização anterior de projeto de graduação na área de Desenho Industrial sobre a RPPN (2000); e o interesse pessoal do autor pelo trabalho, já que é filho do proprietário da RPPN objeto deste estudo.

\section{I - Histórico}

A propriedade Seringal Triunfo está situada no município de Ferreira Gomes, na região central do estado do Amapá. Foi adquirida dois anos após ser anexada ao Brasil, em 1903, pelo Tenente Coronel George Meyer Gonsalves, comandante de Marinha mercante, brasileiro naturalizado, comerciante e proprietário de grandes seringais no rio Araguari. Em seguida foi herdada por seu atual proprietário, Elfredo Felix Távora Gonsalves e seus irmãos, em 1922, após a morte do pai. Entre os anos de 1943 e 1945, durante o período da Segunda Guerra, a mão-de-obra barata geralmente proveniente do Ceará, levou a economia da borracha até o seu auge no estado, diminuindo até meados da década de 60, quando os seringais deixaram de ser arrendados, por conta da inundação de grande parte dos seringais com a chegada do 'progresso'.

Assim, ao construir-se a Represa do Paredão (Hidroelétrica Coaracy Nunes), no rio Araguari, foi inundada, nas duas margens do Rio, uma área de cerca de 3.000 hectares, a maior parte de mata virgem, mata ciliar de vários afluentes e campos de cerrados.

O proprietário da área remanescente da margem esquerda dotado de consistente consciência ambientalista, preocupado com a preservação do ciclo biológico das espécies naturais, para evitar desmatamento da floresta restante e, ainda, para assegurar a permanência dos cursos de água que alimentam a bacia hidrográfica da hidroelétrica, solicitou ao IBAMA, no ano de 1998, o reconhecimento da área de 9.996 hectares como Reserva Particular do Patrimônio Natural Seringal Triunfo, reservando 1.800 hectares para desenvolver atividades agropecuárias e ecoturísticas, sem afetar o equilíbrio ambiental, pedido que foi aceito pelo IBAMA (APÊNDICE 9.2 - págs. 61, 62).

\section{II - Caracterização do Meio ${ }^{9}$}

a) Meio Físico

No diagnóstico do meio físico foram abordados o clima, solos, hidrografia e topografia, compreendidos na microregião.

\section{I - Clima e Classificação Climática}

Dados de temperatura, pluviometria e umidade relativa, foram retirados da estação meteorológica de Porto Platon do Anuário Estatístico do período de 1987-1990.

\footnotetext{
${ }^{9}$ As informações sobre as características biofísicas da Reserva Particular do Patrimônio Natural Seringal Triunfo foram adaptadas pelo autor a partir do Projeto de Criação da Reserva, elaborado pela Engenheira Florestal Marta Maria Sousa Rocha - CREA/AP nº 0110 (1997).
} 
Segundo o IBGE, 1996 - atlas do Amapá, a área compreende o clima sub-úmido, que constitui uma mancha isolada envolvendo a estação de Porto Platon até o Município de Ferreira Gomes. Trata-se de um clima local de causa até agora não identificada. A gênese atmosférica não explica a queda da precipitação aí existente e em desacordo com totais anuais superiores a $2.000 \mathrm{~mm}$ nas áreas circunjacentes. No que concerne ao relevo, nenhuma característica especial justifica o fato climático que, no entanto, parece se refletir nitidamente na vegetação do cerrado que tem aí sua maior expressão.

Nesta área a quantidade de água em excesso atinge apenas a $55 \mathrm{~cm}$ durante o período que se estende de fevereiro a julho.

Na área de déficit moderado que abrange o sudeste do Estado do Amapá, as estações de Porto Platon e Porto Santana registram os seguintes déficits anuais, respectivamente: 31.3 e $30.1 \mathrm{~cm}$. A época de ocorrência de déficits de água se estende de setembro a dezembro. O índice de aridez das estações citadas é 18 classificando-se como do tipo $s$ de Tohrnthwaite ou mais exatamente $p$ uma vez que o déficit é de primavera. Outubro é o mês mais seco. Neste mês o déficit de água atinge a $13.1 \mathrm{~cm}$ em Porto Platon e $12.9 \mathrm{~cm}$ em Porto Santana.

II - Temperatura

A temperatura é elevada em médias anuais em torno de $28^{\circ} \mathrm{C}$. As menores temperaturas ocorreram nos meses de junho e julho e estão acima de $22,1^{\circ} \mathrm{C}$. As maiores ocorreram nos meses de setembro, outubro e novembro e não são superiores a $30,6^{\circ} \mathrm{C}$. A amplitude de variação é de $8,5^{\circ} \mathrm{C}$.

Na estação de Porto Platon, a análise dos registros revela, em termos de temperatura máxima absoluta, que os meses de setembro, outubro e novembro, no período de 1987 a 1990, foram os mais quentes.

Isoladamente o maior valor de temperatura máxima absoluta foi de $36,8^{\circ} \mathrm{C}$ em 1987 , e o menor valor de temperatura mínima absoluta foi de $20^{\circ} \mathrm{C}$ em 1989 e 1990.

\section{III - Pluviometria}

A média de precipitação pluviométrica regional gira em torno de $2700 \mathrm{~mm}$, sendo o período mais chuvoso o compreendido entre dezembro e julho. Há indicação de um excedente hídrico nos sete primeiros meses do ano, entre janeiro e julho. A ocorrência de déficit hídrico dura 4 meses do ano, entre agosto e novembro, sendo de maior intensidade em setembro e outubro. No último mês do ano, dezembro, há equilíbrio na quantidade de água no solo.

A precipitação anual, segundo a Estação Meteorológica de Porto Platon, tem variado entre 2.300 e $2.900 \mathrm{~mm}$ com maior intensidade nos meses de janeiro a maio quando atinge níveis superiores a $500 \mathrm{~mm}$ mensais. 
Os menores índices ocorreram nos meses de agosto a novembro, sendo superiores a $100 \mathrm{~mm}$ mensais. Assim, a variação mensal de precipitação pode atingir níveis superiores a $400 \mathrm{~mm}$ entre o mês de maior e o de menor precipitação.

\section{VI - Umidade Relativa}

Os registros de umidade relativa do ar na Estação de Porto Platon revelam que a menor média anual foi para o ano de 1987, com 80,5\%, e a maior foi para o ano de 1990 com 90,4\%. A média do período de 1987 a 1990 foi de $85,18 \%$.

\section{V - Solos}

Predominam os Latossolos e os solos concrecionários. Ainda importantes são as variedades de solos hidromorficos como os Gley e as Lateritas, especialmente os primeiros nas várzeas dos igarapés e de outros tributários fluviais, onde as condições de drenagem são difíceis.

\section{VI - Hidrografia}

O principal curso d’água na área é o rio Araguari que deságua no oceano Atlântico. Existem vários igarapés, todos tributáveis do rio Araguari, alguns são: Trayra, Bate-bate, Mocambo, Onça, Pedro, Cavalcante, Grande, Eduardo, Galdino, Manoel Jacinto e João Bicudo.

\section{VII - Topografia}

A propriedade tem superfície com Relevo Ondulado Suave.

b) Meio Biótico

Neste projeto a flora e a fauna são caracterizados separadamente. Quando possível, foram apontadas espécies indicadoras da qualidade ambiental com valor científico, econômico, ou raras, ameaçadas de extinção. Com maior detalhe, o meio biótico foi complementado com listas de espécies levantadas através de consultas bibliográficas, observações e amostragens de campo, entrevistas com moradores e trabalhadores da região, caracterização dos tipos de vegetação, dos grupos de animais e a relação entre eles.

\section{I - Flora}

Os tipos de vegetação foram classificados segundo IBGE (1992), em Regiões fitoecológicas separadas em Formações de Savana (cerrado), Floresta Ombrófila Densa e Floresta Ombrófila Densa Aluvial.

A Floresta Ombrófila Densa caracteriza-se por uma alta biodiversidade, produção primária e biomassa. A floresta de árvores emergentes apresenta elevado potencial de madeira e é representado principalmente pelo angelim-pedra, maparajuba, Manilkara sp. e maçaranduba, Manilkara huberi, além de ipê-amarelo, Tabebuia serratifolia, ingá, Inga sp., louro, Nectandra e Cordia sp. e Paxiúba, Iriartia exorrhiza.

A área composta por Floresta Ombrófila Densa com emergentes, possui três estratos bem definidos: um superior composto por árvores emergentes e dominantes de 30 a 40 metros de altura, onde a maioria das espécies têm valor comercial; outro estrato intermediário, composto pela regeneração natural da floresta com árvores dominadas; o terceiro estrato é composto pela 
vegetação rala, composta de herbáceas, arbustos e pequenas plântulas do banco de mudas da floresta.

A Floresta Ombrófila Densa Aluvial é também conhecida por mata-ciliar, pois fixa-se ao longo dos cursos de água, ocupando os terraços antigos das planícies quaternárias como no caso das margens do rio Amazonas e dos seus afluentes. Algumas espécies são: aninga, Ceiba pentandra e Montrichardia arborescens Engl., pracuúba, Mora paraensis, macucu, Licania sp., açaí, Euterpe oleraceae, murumuru, Astrocaryum murumuru e açacú, Hura creptans.

O Campo Cerrado amapaense apresenta características particulares, marcadas principalmente pelo espaçamento de seus indivíduos, nunca inferior a 3,5 metros, sobretudo tortuosos, de casca grossa e rugosa (corticosa). Umiri, Humira balsamifera, tucumã, Astrocaryum vulgare, inajá, Maximiliana regia Mart., ucuúba, Virola surinamensis, ananis, Symphonia globulifera e açaí, Euterpe oleraceae, são espécies encontradas nesta área.

AFloresta Ombrófila Aberta que compõe a grande maioria do projeto, está associada com a vegetação de transição entre esta e a mata-ciliar. Tanto nos pequenos arbustos, quanto nas gigantescas árvores; tanto na quase inqualificável variedade de ervas e capins, quanto no mato rasteiro, propriamente dito, esta flora é inigualável. Ao penetrar nos terrenos baixos e úmidos, encontramos uma vegetação abundante e compacta, enorme quantidade de cipós entrelaçados entre si e nas árvores mais altas, quantidades elevedas de plantas espinhosas, e ervas cortantes.

Ao se chegar no interior da mata, ainda virgem, a vegetação rasteira quase desaparece, surgindo árvores pequenas e medianas, estas procurando subir à procura de luz, por outras mais altas que a circundam. Em geral, fornecem madeira de boa qualidade e possuem fuste retilíneo, justamente pelo sombreamento lateral que força a árvore a buscar luz.

Algumas espécies da flora encontradas na reserva são:

- acapú, Vouacapoua americana Aubl.

- acariquara, Minquartia guianensis Aubl.

- anani, Symphonia globulifera L.

- andiroba, Carapa guianensis Aubl.

- angelim, Hymenolobium sp.

- açaí, Euterpe oleraceae

- amapá, Parahancornia amapa (Hub.)

- bacabinha, Ferdinandusa paraensis Ducke

- bacaba, Ferdinandusa sp.

- breu, Protium sp.

- bacuri-pari, Rheedia sp.

- buriti, Mauritia flexuosa

- carapanaúba, Aspidosperma laxiflorum Kuhl.

- cedro, Cedrela odorata L.

- cumaru, Coumarouna odorata Aubl.

- cupiúba, Goupia glabra Aubl.

- faveira, Parkia sp.

- imbauba, Cecropia sp.

- ingá, Inga sp.

- ipê, Crudia sp.

- itaúba, Mezilaurus itauba (Meissn.) Taub. ex Mez.

- jarana, Eschweilera jarana Ducke

- jatobá, Hymenaea courbaril L.

- louro, Ocotea sp.

- maçaranduba, Manilkara huberi Ducke

- mamorana, Bombax sp.

- marupá, Simaruba amara Aubl.

- matamatá, Eschweilera spp.

- paracaxi, Pentaclethra filamentosa Benth.

- pau-d'arco, Tabebuia serratifolia D. Don.

- pau-amarelo, Euxylophora paraensis Hub.

- pau-ferro, Zollermia paraensis Hub.

- pau-mulato, Chimarris turbinata D. C. 
- pau-roxo, Peltogyne lecointei Ducke

- paxiúba, Iriartia exorrhiza

- piquiá, Caryocar villosum (Aubl.) Pers.

- piquiarana, Caryocar globrum (Aubl.) Pers. C. fabrrum

- pupunha, Bactriz gasipaes

- sumaúma, Ceiba petandra Gaertn.

- sucupira, Himatanthus sucuuba (Spruce) ex Woodson
- sôrva, Simaba simaruba

- seringueira, Hevea guianensis Aubl.

- sapucaia, Lecythis usitata Miers

- taperebá, Spondias lutea L.

- taxi, Tachigalia sp.

- ucuúbas, Virola surinamensis

- umiri, Humiria floribunda Mart.

- uxi, Sacoglottis uchi Hub

\section{II - Fauna}

A área é coberta em grande parte por Floresta Ombrófila Densa, vegetação com influência fluvial (buritizal, juncal e várzea), e o restante por vegetação de Cerrado, o que propicia a ocorrência de uma fauna característica com grande número de espécies e indivíduos, muitas vezes adaptadas à estas condições.

A floresta Amazônica é o bioma mais importante em termos de endemismo e diversidade de espécies. A fauna é bastante variável em cada local, sendo em alguns locais, distinta entre uma margem e outra do rio.

A fauna da propriedade é ainda uma boa caracterização do ecossistema local, em virtude da extensão da área e o pequeno índice de desmatamentos já executados. Deve-se também ao fato de ter grande extensão de sua área ligada a floresta de terras devolutas não utilizadas, ao controle da Usina Hidroelétrica Coaracy Nunes restringir o acesso de pessoas na área, e o proprietário não permitir caça e pesca predatória na propriedade. Ainda existe na região, no entorno desta, áreas de médio a grande porte, cobertas por vegetação nativa que dão abrigo e condições mínimas de desenvolvimento da fauna.

Das informações obtidas referente a fauna, a maior parte trata-se de conversas e questionamentos com moradores da propriedade. Das constatações "in loco", foram avistadas algumas das espécies relacionadas, outras definidas pelos vestígios, como seus rastros, ninhos, restos orgânicos (fezes), e ainda outras pelos sons particulares emitidos, principalmente no que diz respeito às aves (cantos).

Algumas espécies da fauna encontradas na reserva são:

- pirarucu, Arapaima gigas

- piranha, Pygocentrus piraya

- curupeté, Uttiaretichthys sp.

- manduví, Angeneios sp.

- surucucu, Lachesis muta

- jararaca, Bothrops atrox.

- sucuri, Eunectes murinus

- cascavel, Crotalus terrificus

- jabuti, Testudo denticulata

- lagartixa, Hemidactylus mabouya
- inhambú, Tinamus major

- maguari, Ardea cocoi

- garcinha-branca, Egretta thula

- gavião-real, Harpia harpyja

- urubu-rei, Sarcoramphus papa

- gavião carcará/cará-cará, Polyborus plancus

- téu-téu, Vanellus chilensis

- jaçanã, Jacana jacana

- arara-vermelha, Ara macao

- arara-canindé, Ara ararauna 
- piriquito, Brotogeris $s p$.

- corujão orelhudo, Bubos virginianus

- beija-flor-bico-de-lacre, Topaza pella

- anambé-vermelho, Hematoderus militaris

- polícia-inglesa, Leisteis militaris

- onça, Felis sp.

- suçuarana, ariranha, Pteronura brasiliensis

- lontra, Lutra longicaudis

- quati, Nasua nasua

- cachorro-do-mato, Cerdocyon thous

- lobo-guará, Chrysocyon brachyurus

- macaco-prego, Cebus apella

- macaco-da-noite, Aotus trivirgatus
- tatu-canastra, Priodontes maximus.

- tatu-peba, Priodontes sp.

- tamanduá-pretinho, Tamandua longicaudata

- tamanduá-bandeira, Mymecophaga tridactyla

- veado-campeiro, Ozotocerus bezoarticus

- veado-galheiro, Blastocerus dichotomus

- preguiça, Bradypus variegatus

- queixada, Tayassu pecari

- caititu, Pecari tajacu

- anta, Tapirus terrestris

- capivara, Hydrochoerus capibara

- paca, Cuniculus paca

\section{III - Zoneamento e Plano de Proteção da Unidade}

A propriedade em questão, destaca-se por apresentar grande parte da área intacta, mantida com a vegetação nativa. O objetivo é manter a preservação da biodiversidade local e regional e a preservação em local próprio de algumas espécies em extinção. Assim busca-se a diversidade de espécies, o que aumenta a diversidade genética entre os seres e a diferenciação entre os diversos ecossistemas.

A conservação in situ de espécies é de extrema importância, já que os animais e plantas desenvolvem todas as interações com o meio, e onde animais ameaçados de extinção podem procriar e manter refúgios e abrigos sem a alteração do ambiente.

Dessa forma, o proprietário decidiu tornar toda a área da RPPN (9.996 hectares) como zona de proteção integral, deixando a zona de recreação e lazer intensivo e de uso direto, na área da fazenda (1.800 hectares) fora da RPPN (MAPAS 3, 4, 5 - págs. 47, 48, 49). Assim, para a implantação da infra-estrutura do empreendimento não haverá necessidade de desmatamento, sendo que serão utilizados áreas abertas (campos).

O Plano de Proteção da Unidade tem por objetivo a proteção integral das áreas de vegetação densa e de cerrado que existem na RPPN e na fazenda. Deve-se lembrar que apenas uma pequena área da fazenda, que fica fora da RPPN, deve ser modificada para o empreendimento, devidamente acompanhada por um detalhado estudo de impacto ambiental (EIA). A área de uso intensivo é onde estão os acessos às trilhas de interpretação ambiental e às cachoeiras, igarapés e lago da propriedade. 


\section{IV - Capacidade de Carga}

A capacidade de carga se equilibra na harmonia dos interesses do empreendedor ecoturístico, da comunidade local e do ecoturista. Garantir perenidade ao investimento ecoturístico requer medidas que o tornem o menos impactante possível aos atores sociais envolvidos, pois o crescimento dessa atividade, depende da capacidade de suporte do meio ambiente local. Assim, todos os envolvidos são responsáveis pela preservação do patrimônio natural e sócio-cultural, e pela conscientização ecológica desses atores sociais.

Para que condições ecologicamente sustentáveis sejam mantidas, as taxas de crescimento dos sistemas devem ficar abaixo de sua capacidade de suporte. Quando a capacidade máxima de suporte é ultrapassada, a recuperação pode ser irreverssível, o que causará queda da demanda associada à degradação ambiental e terminará por implicar em perdas socioeconômicas e destruição do empreendimento.

Dessa forma, a capacidade de carga para os atrativos, de acordo com o conhecimento prático dos proprietários e a avaliação do projeto de criação da RPPN Seringal Triunfo, será limitada entre 5 a 6 pessoas nas áreas de banho dos igarapés e entre 12 a 15 pessoas nas áreas de banho das cachoeiras e lago. Nos passeios pelo lago da hidroelétrica, o limite é estabelecido pelo tamanho da embarcação utilizada na visita.

Contudo, esta capacidade de carga pode ser atualizada assim que sejam inseridos mecanismos para diminuir o impacto e melhorar as condições de acesso, com equipamentos facilitadores de mobiliário ecoturístico (escadas, rampas, mirantes, bancos, guarda-corpos e abrigos). 


\section{3 - INVENTÁRIO}

O levantamento do potencial ecoturístico da Reserva constituiu-se em pesquisa de campo para reconhecimento da área, percepção das comunidades para a atividade turística e identificação das características sócio-culturais e ambientais que poderiam se apresentar como atrativos turísticos.

\section{1 - ATRATIVOS DO ESTADO DO AMAPÁ ATRATIVOS NATURAIS}

O Amapá tem uma situação única entre todos os Estados da Amazônia, pois fica onde o Rio Amazonas encontra a Linha do Equador e apresenta uma diversidade de paisagens que inclui a Floresta Amazônica, cerrados, campos alagados, lagos interiores e $600 \mathrm{~km}$ de litoral formado de praias e manguezais, influenciados pela foz do Amazonas, por onde flue cerca de $20 \%$ da água doce do planeta. No interior, a serra do Tumucumaque é um ponto de destaque na floresta intocada. A floresta de mata firme, que ocupa $70 \%$ do território, conserva sua biodiversidade praticamente intacta.

O Estado é dominado por três grandes domínios geográficos: amazônico, guianense e oceânico. Por causa dessa característica, o Estado exibe ambientes naturais surpreendentes, diversificados e, principalmente, preservados. Isso se traduz em paisagens bem distintas como planície, campos inundáveis, mangues, cerrados e florestas virgens.

Cerrado, costa de mangues, campos de várzea e campos inundáveis, cercados por imensos lagos navegáveis, compõem essa paisagem singular. A floresta, que domina grande parte do território, está também praticamente intacta, apenas $1 \%$ de sua área de $140.276 \mathrm{~km}^{2}$ foi devastado. Este conjunto se fecha com uma malha extensa de rios, os mais importantes são o Araguari, o maior rio do interior do Estado e onde acontece o fenômeno da pororoca , e o Oiapoque, que faz fronteira com a Guiana Francesa. Estes rios, cheios de cachoeiras e corredeiras, têm grande variedade de peixes, onde se destaca em particular o Tucunaré, peixe símbolo da pesca esportiva.

O Parque Nacional das Montanhas do Tumucumaque é a maior unidade de conservação de florestas tropicais do planeta, e tem 3,8 milhões de hectares, área equivalente ao território da Bélgica, e fica no Amapá, na fronteira com a Guiana. Ultrapassa, em cerca de 270 mil hectares, o parque que antes ocupava o primeiro lugar, o Salonga, localizado no Congo.

A pororoca pode ser um espetáculo aterrador ou fantástico dependendo de onde o espectador estiver. Em segurança, pode-se presenciar a única ocasião em que o oceano Atlântico vence a resistência do rio. Normalmente, o rio Amazonas, por causa do grande volume de água consegue empurrar a água do mar por muitos quilômetros, mas durante a lua nova a situação se inverte. $\mathrm{O}$ choque dessas águas é tão intenso que se reflete em todos os estuários rasos dos rios que desembocam no golfo amazônico. 
No rio Araguari, alguns quilômetros acima do rio Amazonas, esse fenômeno pode ser melhor observado. As ondas atingem até $5 \mathrm{~m}$ de altura e com sua força vão derrubando e arrastando árvores e modificando o leito do rio. Isso acontece todos os dias mas é mais intenso entre abril e junho. Os índios do baixo Amazonas tem uma boa palavra para definir a pororoca: poroc-poroc significa destruidor.

Com esse potencial, o ecoturismo aparece como alternativa econômica natural: atrai investimento e gera riqueza para a população local. No entanto, a fragilidade dos ecossistemas exige um planejamento turístico ordenado para que não haja alteração da paisagem capaz de comprometer o equilíbrio natural.

\section{ATRATIVOS CULTURAIS}

Em sua História, a cidade de Macapá, atual capital do Estado do Amapá, já nasceu com um instinto guerreiro. Seus primeiros habitantes foram casais de açorianos que chegaram à Costa de Macapá, como era então chamado o canal norte do rio Amazonas, em 1751, depois de enfrentar uma longa e arriscada viagem através dos rios. Além da coragem, levavam com eles também a obrigação de colonizar o local e, para consolidar o domínio de Portugal, tinham que impedir a entrada de invasores holandeses, irlandeses, ingleses e, principalmente, franceses.

Treze anos mais tarde, começa a ser construída a Fortaleza de São José . Os negros que trabalharam na obra fundaram um quilombo que deu origem a Vila de Curiaú onde hoje vivem apenas descendentes desses escravos que mantiveram as tradições de seus ancestrais. Macapá é cortada pela Linha do Equador e dá ao turista a exata sensação do que é estar no meio do mundo.

Quem visita a Vila de Curiaú, que fica a 12 km de Macapá, e hoje é uma Área de Proteção Ambiental, tem a sensação que o tempo não passou. A vila é habitada apenas por negros descendentes dos escravos que participaram da construção da Fortaleza de São José e seus atuais habitantes preservam, com cuidado, toda a cultura que herdaram. O Marabaixo é uma das manifestações culturais mais autênticas. Esta festa em homenagem ao Divino Espírito Santo, é marcada pela música e dança tipicamente africanas. Além dessa, há a Festa de São Joaquim em agosto.

A Fortaleza de São José edificada no estilo Vauban, foi construída a partir de uma grande muralha de pedra. Os portugueses tomaram a decisão de construir este complexo militar para garantir o domínio sobre o extremo norte do Brasil Colonial constantemente ameaçado pelos invasores estrangeiros no século XVIII. A obra começou em 1764 e só ficou pronta em 1782, dezoito anos mais tarde. Índios e, principalmente, negros foram utilizados como mão-de-obra escrava. Parte dessa história está presente na Vila de Curiaú, remanescente quilombola onde vivem apenas os descendentes desses negros que conservam a cultura e a tradição de seus ancestrais. 
A Fortaleza é a maior fortificação construída pelos portugueses no Brasil e por causa dessa importância história e da sua arquitetura foi elevada a categoria de patrimônio nacional em 1950.

Na questão indígena, o Amapá é o primeiro estado brasileiro a ter todas as terras indígenas demarcadas. Nas duas grandes reservas, que representam 8,6\% de todo o território estadual, 140.276 km 2, vivem as etnias - Galibi, Karipuna, Palikur, Waiapi e Galibi Marworno.

Cada aldeia indígena tem um padrão estético que se reproduz nos objetos utilitários como cestas, redes, adornos e armas. Feitos com madeira, fibras, cerâmica, sementes, plumagem, dentes e ossos de animais, Alguns desses objetos são enfeitados com penas de aves ou pintados com corantes naturais extraídos de cascas de árvores ou sementes como as do urucum.

O artesanato é uma das fontes de renda dos povos indígenas do Amapá. Os Karipuna, por exemplo, fabricam colares de contas ou ossos. Os Waiapi usam desenhos mitológicos para explicar suas origens. Os Apalai do norte do Pará fazem complexos desenhos geométricos com significados conhecidos apenas pelo grupo.

Destaca-se ainda a Gastronomia riquíssima do estado com seus pratos tradicionais como o Tacacá, a Maniçoba, o Pato-no-Tucupi e o Açaí preparado na hora; e pelos doces e compotas de frutas nativas como o Cupuaçu, o Bacuri, a Bacaba, o Buriti, etc.

Contudo, sua localização estratégica dá ao Amapá um grande horizonte para o turismo internacional, já que a Guiana Francesa é a fronteira brasileira com a França e a Europa, e onde os fluxos Brasil-Guiana e vice versa, constituem-se num importante fator comercial, com possibilidades de futuros fluxos ecoturísticos.

\section{2 - ATRATIVOS E INFRA-ESTRUTURA DA RESERVA ATRATIVOS NATURAIS}

A propriedade possui grande número e variedade de atrativos naturais como cachoeiras, corredeiras, lago formado pela hidroelétrica do Rio Araguari, igarapés, terra firme, campos de cerrado, áreas de inundação e floresta densa. A grande diversidade de ecossistemas é habitada por uma diversidade semelhante de animais silvestres - alguns em vias de extinção.

Os atrativos naturais mais procurados pelos proprietários, familiares, amigos e estudantes:

- Rio Araguari: rio de cor verde, aparência cristalina a turva e temperatura natural que margeia os quase $30 \mathrm{~km}$ da propriedade, onde banha todo o limite sul da RPPN, forma o lago na Hidroelétrica Coaracy Nunes, e após produzir energia nas turbinas da represa, forma as corredeiras que banham a prainha ao sul da fazenda, seguindo para o oceano; 
- Corredeiras da prainha (FIGURAS 16, 17 - pág. 55): praia de areia branca, localizadas logo abaixo da hidroelétrica, ao longo do rio Araguari, onde predomina o bioma Cerrado; a barragem proporciona diferentes níveis de corredeiras, de acordo com a proximidade do inverno ou do verão, ideais para a prática do rafting, da canoagem e do bóia-cross;

- Lago da represa (FIGURAS 2, 10, 11, 12, 13 - págs. 50, 53, 54): localizado acima da hidroelétrica, ao longo do rio Araguari, é a fronteira da RPPN propriamente dita, de 9.996 ha de proteção integral, onde predomina o bioma amazônico; tem cor escura e aparência turva devido a quantidade de matéria orgânica em decomposição que é represada; com um barco é possível fazer observação de pássaros e animais silvestres na RPPN, além de canoagem e de pesca amadora ou esportiva no lago da represa; dentro da Reserva Seringal Triunfo, no sentido oeste para leste (ao longo da margen esquerda do rio Araguari) vê-se a foz de: Igarapé João Bicudo, Igarapé Manoel Jacinto, Igarapé Galdino, Igarapé do Eduardo, Igarapé Major Moreira, Igarapé Grande, Igarapé Cavalcante, Igarapé da Onça, Igarapé Mocambo e Igarapé Bate Bate;

- Igarapé Traíra (FIGURA 18 - pág. 55): cor verde, aparência cristalina e temperatura entre $20^{\circ}$ e $25^{\circ} \mathrm{C}$, localizado no limite norte da propriedade, numa mancha de Cerrado, com mata ciliar e de galeria exuberante, deságua logo abaixo das corredeiras da prainha, no rio Araguari; existem pelo menos três bons pontos de "banho" ao longo do Traíra.

No entanto, a grande dimensão da propriedade e a impossibilidade de fiscalização da mesma, pelo proprietário e pelo órgão competente, facilitou o acesso de alguns invasores que praticaram pequenos desmatamentos nas áreas de melhor acesso, como o leito de alguns igarapés que nascem fora da Reserva e alimentam o lago da Hidroelétrica.

No plano estadual, a localização central permite a RPPN estar equidistante de outras áreas de proteção da natureza no Estado, o que é fator importante para a manutenção da biodiversidade na RPPN, bem como para o intercâmbio de idéias e de público. São elas: Parque Nacional Montanhas do Tumucumaque; Parque Nacional Cabo Orange; Floresta Nacional do Amapá; Parque Indígena do Oiapoque; Parque Indígena dos Waiapi; Parque Indígena do Tumucumaque; Parque Indígena Uaçá, Galibi e Juminã; Área de Proteção Ambiental Quilombola Vila Curiaú; Reserva de Desenvolvimento Sustentável do Rio Iratapuru; Reserva Extrativista do Rio Cajarí; Estação Ecológica das Ilhas Maracá-Jipioca; Estação Ecológica do Jari, a Área de Proteção Ambiental do Rio Curiaú; Reserva Biológica do Lago Piratuba; Reserva Biológica da Fazendinha; Reserva Biológica do Parazinho; além de outras quatro RPPNs (MAPA 1 - pág. 45).

Também constitui um atrativo a nova modalidade de surf na pororoca realizada no baixo Rio Araguari. Normalmente, o rio Amazonas, por causa do grande volume de água consegue empurrar a água do mar por muitos quilômetros, mas durante a lua nova a situação se inverte, provocando grandes ondas e de longa duração. Surfistas do mundo inteiro passaram a visitar o Estado, que fora da rota tradicional de turismo, não possuía tamanho movimento de visitantes. 


\section{ATRATIVOS CULTURAIS}

Dentre os atrativos culturais destaca-se as comunidades locais com suas habitações tradicionais da amazônia e a realidade de seus ocupantes: índios, seringueiros, castanheiros e caboclos ribeirinhos.

A história da propriedade também merece destaque na visitação da Reserva. O território hoje conhecido entre os rios Oiapoque e Araguari foi questão de disputa internacional entre o Brasil e a França (Guiana Francesa) no início do século XX, sendo anexado ao Brasil em 1901 com o nome de Aricary (do Tupi ari: palmeira e; cari: branco, gente, povo) ${ }^{10}$.

Outro fato interessante foi a produção de látex no Seringal Triunfo destinado à $2^{\mathrm{a}}$ Guerra Mundial (entre os anos de 1943 e 1945). Com a inundação causada pela construção da represa, quase todas as seringueiras morreram, pois estas apareciam próximas às margens do Rio Araguari.

\section{INFRA-ESTRUTURA}

A propriedade em questão, destaca-se por apresentar grande parte da área intacta, mantida com a vegetação nativa. As partes utilizadas se fizeram na construção de 5 casas rurais, 2 depósitos, 2 currais, 100 hectares de roçados e pastagens cultivadas, 4.000 metros de cercas e 1.451 hectares inundados pela construção da Usina Hidroelétrica Coaracy Nunes (FIGURAS 7, 8, 9 - pág. 52).

Com a introdução da Reserva Particular do Patrimônio Natural, houve uma melhoria na utilização da área, cooperando para um desenvolvimento e conscientização ambiental na região, uma vez que associa a manutenção e preservação dos recursos naturais renováveis.

A seguir os principais aspectos sobre a infra-estrutura da propriedade:

- Segurança pública: O município de Ferreira Gomes possui Polícia Militar Florestal e Bombeiros para atender ocorrências;

- Segurança nos atrativos: Os passeios na Reserva apresentam os riscos comuns a programas de ecoturismo em rios e matas, principalmente picadas, afogamento e quedas. No entanto, o ambiente é favorável ao desenvolvimento de produtos com baixo risco de acidentes;

- Energia: A reserva possui energia elétrica, instalada em 2000, e ainda, um gerador à diesel, para emergências e atividades variadas;

\footnotetext{
${ }^{10}$ Livros consultados na tradução: SILVEIRA BUENO, F. 1990. Vocabulário Tupi-Guarani-Português. Editora Universidade de São Paulo. São Paulo; TIBIRIÇÁ, L. C., 1984. Dicionário Tupi-Português: com esboço de gramática de Tupi antigo. Traço Editora; e TIBIRIÇÁ, L. C., 1989. Dicionário Guarani-Português. Traço Editora.
} 
- Vias de acesso: A estrada asfaltada que liga a Reserva a Macapá (BR 156), e corta o Estado de norte a sul, é transitável durante todo o ano, mas fica em condições ruins na estação das chuvas (MAPA 2 - pág. 46). Para se ter acesso à fazenda, é preciso passar por duas guaritas da Eletronorte (FIGURAS 1, 4 - págs. 50, 51), localizadas nas duas margens da represa, e identificar-se para os vigilantes. Uma vez dentro da propriedade, a acessibilidade aos atrativos é segura e permanente;

- Comunicação: A instalação , em 2000, de uma pequena antena na propriedade, possibilita que o sinal da telefonia celular dê cobertura a toda a área que compreende fazenda , lago e reserva;

- Hospedagem e leitos: Não há na Reserva nenhum meio regular de hospedagem. Todos os pernoites são feitos em redes e colchões na sede e em mais duas casas da propriedade, onde cada uma das casas comporta em torno de 10 redes e 10 colchões;

- Alimentação: Não há na Reserva nenhum estabelecimento comercial de alimentação ou refeitório. Todas as casas possuem fogão e água corrente, mas as refeições são preparadas na sede da propriedade, onde estão os freezeres e geladeiras;

- Higiene: Além da água utilizada para banhos, preparo de alimentos e consumo, ter boa qualidade, a presença de fossa é outro importante fator para demanda ecoturística;

- Saúde: O Município de Ferreira Gomes, a 6 km, possui farmácias, pronto-socorro público, mas a assistência médica para casos mais graves como acidentes tem que ser feita na capital, a $150 \mathrm{~km}$. A ocorrência de doenças como Malária tem diminuido mas ainda tem-se conhecimento de casos isolados em certas áreas e regiões;

\section{3 - LOCALIZAÇÃO E ACESSO}

Plantas do imóvel, indicando limites e confrontantes da propriedade, área da Reserva e sua localização no estado, município ou região estão nos mapas em anexo (ANEXOS 8.2 - pág. 44).

- Endereço: Margem esquerda do Rio Araguari, municípios de Ferreira Gomes e Porto Grande;

- Proprietários: Elfredo Felix Távora Gonsalves e Maria Darcy Colares Gonsalves;

- Área Total da Propriedade: 12.495,2 hectares;

- Área Total da RPPN: 9.996 hectares;

- Cartório: Registro de Imóveis da Comarca de Amapá;

- Portaria: $\mathrm{n}^{0} 89$ / 98 - N;

- Frente: margem esquerda do rio Araguari, numa profundidade de aproximadamente 6 km;

- Fundo: área da Chamflora Amapá Agroflorestal LTDA e terras devolutas;

- Limite Sul RPPN (rio a cima): Igarapé João Bicudo (a montante), até cerca de $30 \mathrm{~km}$ rio a baixo;

- Limite Norte RPPN (rio a baixo): Igarapé Bate-bate (a jusante);

- Latitude: $00^{\circ} 12^{\prime} 38^{\prime \prime}$ a $00^{\circ} 26^{\prime} 46^{\prime \prime}$;

- Longitude: $51^{\circ} 12^{\prime} 06^{\prime \prime}$ a 51²7’41”. 
O acesso para a Reserva é simples e leva em média uma hora e meia de automóvel. Via de acesso asfaltada à propriedade: BR 156 - Macapá / Seringal Triunfo (sede da propriedade):

- Acesso 01: à partir de Macapá, 147 quilômetros (BR 156) até o ramal do Paredão (AP 010);

- Acesso 02: à partir de Macapá, 157 quilômetros (BR 156) até a altura do ramal do Teimoso (AP 010) $4 \mathrm{~km}$ e ramal do campo de pouso da Eletronorte, 8km. Este acesso raramente é utilizado pelos proprietários que tentam recuperar a área.

A frequência de vôos de várias empresas aéreas para Macapá é grande, com saídas diárias durante quase toda a semana, das principais capitais brasileiras, como Manaus, São Paulo, Rio de Janeiro e Brasília, com preços que variam de $\mathrm{R} \$ 600,00$ a $\mathrm{R} \$ 800,00$. Além de conexões com as principais cidades do Brasil e com Belém, aonde chega vôo internacional de Miami e tem vôo direto de Cayenne (Guiana Francesa) a um custo acessível (cerca de US\$ 90,00).

\section{4 - ORGANIZAÇÕES GOVERNAMENTAIS E NÃO-GOVERNAMENTAIS ${ }^{11}$}

- CEMA (Coordenadoria Estadual de Meio Ambiente - 096 223-1551): organização governamental, que tem por objetivos zelar pelo meio ambiente, através de ações fiscalizatórias e da educação ambiental.

- CNS/AP (Conselho Nacional dos Seringueiros - 096 222-4453): organização nãogovernamental, que tem por objetivos proteger o meio ambiente, em especial a Amazônia, buscar desenvolvimento sustentáveldas populações tradicionais - extrativistas, e desenvolver políticas públicas pelo setor extrativista.

- DETUR (Departamento de Turismo - 096 241-1138): organização governamental, que tem por objetivos apoiar, fomentar e implantar o turismo no estado, dentro das políticas da Amazônia legal.

- EMBRAPA (Empresa Brasileira de Pesquisa Agropecuária - 096 241-1551): organização governamental, que tem por objetivos gerar, adaptar, difundir e transferir tecnologias referentes aos sistemas de produção agroflorestal.

- IBAMA (Instituto Brasileiro do Meio Ambiente e dos Recursos Naturais Renováveis - 096 223-3635): organização governamental, que tem por objetivos formular, coordenar, executar e fazer executar a política nacional do meio ambiente e da preservação, conservação e uso racional, fiscalização, controle e fomento dos recursos naturais renováveis.

\footnotetext{
${ }^{11}$ As informações sobre organizações governamentais e não-governamentais, hospedagem, restaurantes e agências de viagens do Amapá foram extraídas do inventário e diagnóstico da Reserva Extrativista do Rio Cajarí, desenvolvido em conjunto por Grupo Nativa, Centro Nacional para o Desenvolvimento das Populações Tradicionais, MMA, SCA e PPG7 em 1998.
} 
- SOPREN/AP (Sociedade de Preservação aos Recursos Naturais e Culturais da Amazônia 096 222-0644): organização não-governamental, que tem por objetivos pugnar pelaproteção e exploração racional da floresta, fomentar a produção de mudas, divulgar a educação ambiental e sanitária, pugnar pela conservação da natureza e pela necessidade da reanimação cultural.

- SEBRAE/AP: organização mista de apoio e fomento à micro e pequenas empresas, de atuação nacional, vias regionais independentes. É uma das entidades que mais tem dado apoio ao desenvolvimento do turismo, principalmente na área de capacitação. O SEBRAE/AP ainda não desenvolveu nenhum trabalho específico na área, mas tem interesse e recursos para efetuar parcerias.

\section{5 - HOSPEDAGEM, RESTAURANTES E AGÊNCIAS DE MACAPÁ}

Hospedagem

Convenções: a)Categoria: simples, médio conforto, confortável, muito confortável, luxo;

b)Aparência: boa, regular, ruim (para cliente com perfil ecoturista).

- Novohotel (096 223-1144): 76 apartamentos, 160 leitos, médio conforto, ar condicionado, frigobar, tv, telefone, aparência boa, preço $\mathrm{R} \$ 130,00$ a $\mathrm{R} \$ 180,00$.

- Pousada Equinox (096 222-4378): 14 apartamentos, 28 leitos, conforto simples, ar condicionado, frigobar, tv, telefone, aparência boa, preço R \$ 80,00 a R \$100,00.

- Hotel Atalanta (096 223-1612): 28 apartamentos, 60 leitos, conforto simples, ar condicionado, frigobar, tv, telefone, aparência boa, preço R\$ 80,00 a R \$ 100,00.

- San Marino (096 223-1522): 30 apartamentos, 65 leitos, conforto simples, ar condicionado, frigobar, tv, telefone, aparência boa, preço R \$ 80,00 a R \$ 100,00.

- Frota (096 222-4488): 33 apartamentos, 70 leitos, conforto simples, ar condicionado, frigobar, tv, telefone, aparência regular, preço $\mathrm{R} \$ 70,00$ a R \$ 90,00.

\section{$\underline{\text { Restaurantes }}$}

Convenções: a)Conforto: simples, médio conforto, confortável, luxo; b)Aparência: boa, regular, ruim; c)Cozinha: muito boa, boa, regular, ruim.

- Martinho's Peixaria: conforto simples, especialidade pescados, aparência ruim, ambiente regular, cozinha muito boa, preço $\mathrm{R} \$ 10,00$ por pessoa.

- Parati: conforto simples, ar condicionado, especialidade variada, aparência boa, ambiente agradável, cozinha muito boa, preço R\$ 15,00 por pessoa.

- Pousada Equinox (096 222-4378): conforto simples, especialidade internacional, aparência boa, ambiente agradável, cozinha muito boa, preço R \$20,00 por pessoa.

\section{Agências de viagem}

- Amapá Viagens e Turismo (096 223-2667): Avenida Francisco Azarias Neto 17 / loja. 01.

- Antares Viagens e Turismo (096 223-9933): Rua Hamilton Silva 1065.

- Fênix Turismo (096 223-8200): Rua Cândido Mendes 374 / sala 88C.

- Marco Zero Viagens e Turismo (096 222-1922): Rua São José 2048 / sala 06. 


\section{6 - PONTOS POSITIVOS E NEGATIVOS}

\section{Pontos positivos}

- O Rio Amazonas, a região amazônica e a linha do equador oferecem grande apelo de mercado;

- Áreas de beleza cênica preservadas e diversidade de ecossistemas na mesma propriedade;

- Ausência de qualquer poluíção da água ou do ar;

- A beleza cênica da RPPN Seringal Triunfo vista do lago da represa (e pelos quase $30 \mathrm{~km}$ rio acima) e a sua definição como Zona de Proteção Integral, são o grande diferencial desta RPPN;

- As praias e corredeiras na parte baixa do rio Araguari formam um cenário de Cerrado em plena Floresta Amazônica;

- A Hidroelétrica Coaracy Nunes é um colosso no meio da floresta, e pode auxiliar na educação de estudantes como exemplo de impacto ambiental não-planejado;

- Fartura, variedade e quantidade de verdadeiros pomares nativos de frutas como açaí, cupuaçu, bacába, cajú, manga, banana, buriti, entre outros, dentro da fazenda;

- Alta diversidade dos produtos de artesanato local (tradicional e indígena);

- Proximidade com a Guiana Francesa, favorecendo a entrada no mercado europeu;

- Cidade-acesso (Macapá) é bastante agradável e oferece boas possibilidades de visitação em seu entorno;

- Governo estadual empenhado no desenvolvimento da atividade turística; e

- O Amapá é novidade até para os brasileiros.

\section{$\underline{\text { Pontos negativos }}$}

- Propriedade afetada por represa hidroelétrica;

- Ocorrência de poluíção sonora nas proximidades da represa;

- Ocorrência de poluíção visual pelas torres de transmissão de energia que cortam a fazenda;

- Número reduzido de turistas regionais, nacionais e internacionais no estado;

- Preços elevados de passagens aéreas nacionais e internacionais quando comparados a produtos internacionais e mesmo nacionais;

- Existência de doenças tropicais endêmicas, em especial a malária;

- Não existem estruturas adequadas para hospedagem e alimentação de visitantes; e

- Comunidade da Vila Paredão e da cidade de Ferreira Gomes, próximas à RPPN, não capacitadas para operação e receptivo. 


\section{4 - DIAGNÓSTICO ECOTURÍSTICO}

O diagnóstico avaliou a partir da discussão dos resultados do inventário, qual é a demanda de ecoturistas e os possíveis parceiros locais para o desenvolvimento do ecoturismo no Amapá.

\section{1 - AVALIAÇÃO DE DEMANDA}

O perfil do ecoturista brasileiro, segundo dados de importantes operadoras do mercado, mostra que os maiores interessados neste tipo de turismo são os jovens de 25 a 40 anos, grande parte oriundas de grandes e conturbados centros urbanos. Geralmente, estes têm médio poder de compra, são solteiros e detém um bom nível de educação e cultura. É comum que este ecoturista viaje em grupos organizados por operadoras nacionais de ecoturismo em feriados prolongados e férias. Estes também costumam associar alguma atividade esportiva à visitação (WWF-Brasil, $2003)^{12}$.

A Embratur (2002) aponta ainda, outros dados importantes sobre as preferências do turista brasileiro, são eles:

- Meio de transporte utilizado: ônibus (36\%); carona - viagem em carro de amigos (9,9\%); e avião (9\%);

- Meio de hospedagem utilizado: casa de amigos (65,9\%); hotéis (15\%); e pousadas (5\%);

- Gasto médio dos turistas brasileiros foi de R \$419,00 por viagem. Porém quem ganha mais de $\mathrm{R} \$ 3.000,00$ por mês, gasta $\mathrm{R} \$ 1.800,00$ numa viagem;

- O perfil médio do viajante brasileiro diz que sua renda média mensal é de R\$ 860,00 e que ele não fez faculdade;

- Uma das tendências mundiais é a regionalização das viagens. No caso brasileiro, $70 \%$ dos turistas viaja na região em que reside.

No entanto, segundo o Governo do Estado do Amapá, em 1995, foram registrados 83.665 desembarques em Macapá, o que levaria a seguinte estimativa de mercado:

\begin{tabular}{|l|c|c|}
\hline \multicolumn{1}{|c|}{ ANO 1995 } & \% turistas & \% ecoturistas \\
\hline Desembarques no ano & 5.857 & 586 \\
\hline Potencial RPPN (3\% desembarques) & 2.510 & 251 \\
\hline
\end{tabular}

Tabela 1: Estimativa de Mercado (Governo do Estado do Amapá, 1995).

Como podemos identificar na tabela, a estimativa do mercado atual de ecoturistas em Macapá indica um número pequeno de visitantes no Estado, onde a grande maioria dos visitantes que chega no Amapá está lá por razões profissionais e não de lazer (Governo do Estado do Amapá, 1995).

\footnotetext{
${ }^{12}$ Adaptado pelo autor a partir de WWF-Brasil (2003).
} 
Nota-se que três grupos de visitantes em Macapá: os que vem por motivações profissionais; a busca pela pesca esportiva; e a nova modalidade de surf na pororoca realizada no baixo Rio Araguari. O esporte tem atraído um fluxo de turistas e, especialmente, surfistas nas temporadas de lua nova, quando grandes ondas e de longa duração se formam nos rios da região (pororoca). Outro público-alvo desse estudo, são os associados à modalidades de hospedagem coletivas, como os Albergues da Juventude, famosos em todo o mundo. Os albergues têm público fiel e demanda garantida de viajantes com o perfil do ecoturista nacional e internacional.

Assim, a tendência do visitante estando na capital, são as visitas aos atrativos naturais e culturais de fácil acesso no entorno da capital (até $80 \mathrm{~km}$ do centro de Macapá), como a APA Quilombola Vila Curiaú, a APA da Fazendinha, a Fortaleza de São José de Macapá, o Marco Zero do Equador, entre outros, e posteriormente, aos atrativos de acesso asfaltado a média distância (até 160 km do centro de Macapá).

Os únicos acessos à Macapá são por via aérea ou por meio de transportes fluviais provenientes de Belém. Isso torna a chegada à Macapá sempre um espetáculo inesquecível para o visitante, com a imensidão da foz do rio Amazonas e a grandiosidade da floresta tropical equatorial.

No entanto, o mercado turístico regional não é significativo, já que está fora da rota tradicional de turismo, mas pode se favorecer em função da plenitude de sua natureza, de ser uma área de livre comércio (zona franca) e dos barcos turísticos em travessia pelo Amazonas.

\section{2 - PARCERIAS LOCAIS}

O local propicia condições únicas de pesquisa abordando diversas interações no ambiente. Incontáveis setores de pesquisa científica e educação ambiental podem ser desenvolvidas, tais como: identificação e comportamento de animais, vegetais e microorganismos; interação entre seres vivos e meio em que vivem (ecologia); solos florestais; processos geológicos; índice de diversidade inter, intra-específico e entre populações; evolução; regimes hídricos; entre outros.

Deverão ser firmados convênios com universidades, institutos como o INPA - Instituto Nacional de Pesquisa na Amazônia, ONG's, empresas privadas e órgãos que queiram desenvolver pesquisa em um ambiente selvagem. Também serão firmadas parcerias com a população local através de formas mais democráticas de gestão dos recursos naturais, por meio da participação integrada via cooperativismo, associativismo e co-gestão.

Entre as principais parcerias que poderão ser firmadas com a RPPN Seringal Triunfo, para o desenvolvimento de ecoturismo, destacam-se:

- O Departamento de Turismo (DETUR) e a Coordenadoria Estadual de Meio Ambiente (CEMA) são órgãos do governo estadual que desenvolvem ações voltadas ao incentivo da atividade turística, especialmente o ecoturismo. As ações envolvem todo o Estado e já contam com recursos para realização de inventário e monitoramento da atividade turística, com a idéia de se criar um corredor de atrativos com estrutura mínima de receptivo. O DETUR e a CEMA também estão empenhados na promoção do Amapá como destino turístico. Assim, a atividade ecoturística na RPPN Seringal Triunfo estaria dentro de um grande roteiro, colaborando com a 
formação de um pólo ecoturístico no Estado e se beneficiando dos diversos resultados das ações do DETUR e da CEMA.

- Em diversos estados brasileiros o SEBRAE vem desenvolvendo um papel importante no incentivo, na capacitação e no monitoramento da atividade turística. O SEBRAE-AP já desenvolve ações a nível de capacitação profissional e está auxiliando o DETUR e a Secretaria de Meio Ambiente nas atividades de inventário e monitoramento turístico.

- Os proprietários da Pousada Equinox, localizada em Macapá, têm experiência, contatos e clientes com o perfil ecoturístico. Uma estrutura receptiva e roteiros na RPPN Seringal Triunfo podem oferecer outras opções aos clientes da pousada, aumentando a permanência desses no Estado.

- As agências turísticas de Macapá, Fênix, Topaza e Manganês, se associaram para oferecer produtos regionais aos clientes. Estas agências podem fazer um papel importante de interlocução entre o produto RPPN, o mercado regional, operadoras nacionais e internacionais. Além disso, colaboram na divulgação do ecoturismo na Reserva e também podem desempenhar as atividades de receptivo quando da chegada de turistas para o roteiro na RPPN. Uma parceria entre as agências e operadoras de turismo de Macapá e da Guiana Francesa, ofereceria programas conjuntos entre os dois países, diversificando as opções do turista internacional e facilitando a entrada do produto RPPN Seringal Triunfo no mercado francês. 


\section{5 - RECOMENDAÇÕES PARA A IMPLANTAÇÃO}

A proposta apresentada neste capítulo definiu, a partir da discussão dos resultados do inventário, quais potenciais produtos ecoturísticos a Reserva pode oferecer e o público-alvo para estes produtos. São sugeridos procedimentos de implantação e treinamento, tecnologia de construção, sistemas de operação, modalidades de produtos e uma série de observações para subsidiar o planejamento e implantação do ecoturismo.

A Cúpula de Especialistas em Ecoturismo recomenda ao setor privado: "garantir a utilização de materiais, produtos, logística e recursos humanos locais em suas operações de forma a manter a autenticidade da atividade de ecoturismo e ampliar os benefícios financeiros ao destino. Para que isso seja possível, é necessário também que se invista no treinamento e na capacitação da mãode-obra local” (Carta de Quebec, item B-22, Canadá, 2002).

Dessa forma, as propostas, estratégias de uso e recomendações para a implantação da atividade ecoturística na RPPN foram desenvolvidas visando: proteger e desenvolver os atrativos ecoturísticos; melhorar e implementar infra-estrutura básica necessária para viabilizar o aumento controlado do fluxo turístico para a região; capacitar recursos humanos; valorizar as culturas locais; e contribuir para a conservação daquela biodiversidade.

\section{1 - PRODUTOS E ROTEIROS}

A zona de recreação e lazer intensivo e de uso direto será na área de cerca de 1.800 hectares da fazenda, portanto fora da RPPN, pois o proprietário optou por tornar toda a área da RPPN de 9.996 hectares, em zona de proteção integral por se tratar de floresta densa de terra firme, onde nascem diversos igarapés que alimentam a bacia do rio Araguari.

Dessa forma, a zona de recreação, lazer e uso direto utilizaria uma área de até 30 hectares para uso extensivo dos chalés e uma área de não mais que 200 hectares de uso intensivo, definidas após o devido Estudo de Impacto Ambiental, definindo os acessos às trilhas de interpretação ambiental e às cachoeiras, igarapés e lago da represa.

Na diversidade de ecossistemas, subir os quase 30 quilômetros de RPPN ao longo do rio Araguari de canoa ou barco a motor, ou fazer um passeio à cavalo, ou de bicicleta de montanha na fazenda, são atividades de baixo impacto compatíveis que já são realizadas pelos proprietários, familiares e amigos. Há potencial para serem organizadas excursões temáticas ao local, tais como observação de orquídeas, de aves, recursos hídricos, entre outros.

Estima-se que o tempo ideal para se conhecer os atrativos naturais da RPPN Seringal Triunfo pode ser de cinco dias a uma semana. Assim, o visitante que tenha apenas um dia livre, pode fazer o passeio de um dia (bate-e-volta), que será preferencialmente, para a visita de interpretação ambiental ao lago que margeia a Reserva. 
Além dos ecoturistas, a meta desse produto é um intensivo trabalho de educação ambiental visando despertar a consciência ambiental nas populações próximas à área. Para isso, seriam realizadas visitas explicativas à região, incentivando-se alguns costumes locais e instruindo a população para evitar queimadas, desmatamentos desnecessários, poluição, etc. Após capacitada, a população nativa e/ou do município participará da gestão do local como funcionário da RPPN, guia para os turistas e na produção de artesanato, biscoitos, compotas, doces e de produtos da região, que seriam comercializados no entreposto do centro de visitantes.

\section{ROTEIRO I: 3 dias, 2 noites}

Este roteiro é destinado aos potenciais turistas interessados em passar três dias realizando visitas a atrativos culturais, naturais e históricos, na cidade de Macapá e no destino principal da viagem que é a RPPN Seringal Triunfo. Avaliando a demanda de viajantes que vêm ao estado por razões profissionais, este roteiro foi desenvolvido para atender a todas as faixas etárias, mas, principalmente, grupos escolares, familiares e de terceira idade, por conta do médio/baixo grau de dificuldade dos atrativos.

Logística operacional: os deslocamentos deverão ser feitos através de vans e/ou microônibus alugados à partir da cidade origem Macapá. A infra-estrutura de hospedagem, alimentação e guiagem será providenciada pela Reserva. Os deslocamentos pelo interior da RPPN poderão ser feitos por caminhão-jardineira, veículos comuns, caminhadas, bicicletas de montanha ou cavalo.

Dia 01 - Macapá:

Tarde: Chegada em vôo doméstico ao Aeroporto de Macapá;

Noite: Translado, acomodação, jantar e pernoite na Pousada Equinox;

Dia 02 - Macapá $\rightarrow$ RPPN Seringal Triunfo:

Manhã: Passeio em canoa/remo pelo lago da hidroelétrica e interpretação do ambiente amazônico;

Tarde: Banhos nos igarapés, visita às manchas de cerrado e observação de aves ao fim da tarde;

Noite: Atividades culturais no centro de visitantes, jantar e pernoite na Reserva.

$\underline{\text { Dia } 03}$ - RPPN Seringal Triunfo $\rightarrow$ Macapá:

Manhã: Visita à áreas degradadas em recuperação, com o plantio de uma muda nativa pelo turista;

Tarde: Banhos nas cachoeiras do rio Araguari;

Noite: Retorno à Macapá, à Pousada Equinox ou embarque para a cidade de origem. 


\section{ROTEIRO II: 5 dias, 4 noites}

Este roteiro é destinado aos potenciais turistas interessados em passar cinco dias realizando visitas a atrativos culturais, naturais e históricos, na cidade de Macapá e no destino principal da viagem que é a RPPN Seringal Triunfo. Avaliando a demanda de viajantes que vêm ao estado por razões profissionais, este roteiro foi desenvolvido para atender a grupos e casais com idade entre 20 e 40 anos, por conta do alto/médio grau de dificuldade dos atrativos.

Logística operacional: os deslocamentos deverão ser feitos através de vans e/ou microônibus alugados à partir da cidade origem Macapá. A infra-estrutura de hospedagem, alimentação e guiagem será providenciada pela Reserva. Os deslocamentos pelo interior da RPPN poderão ser feitos por caminhão-jardineira, veículos comuns, caminhadas, bicicletas de montanha ou cavalo. Neste roteiro, no trecho percorrido entre a RPPN Seringal Triunfo e o município de Cutias, no baixo rio Araguari, será utilizado além do transporte terrestre, o barco a motor (lancha voadeira $^{13}$ ), que fará o transporte até o local exato da pororoca.

Dia 01 - Macapá:

Tarde: Chegada em vôo doméstico ao Aeroporto de Macapá;

Noite: Translado, acomodação, jantar e pernoite na Pousada Equinox;

Dia 02 - Macapá $\rightarrow$ RPPN Seringal Triunfo:

Manhã: Passeio em canoa/remo pelo lago da hidroelétrica e interpretação do ambiente amazônico;

Tarde: Banhos nos igarapés, visita às manchas de cerrado e observação de aves ao fim da tarde;

Noite: Atividades culturais no centro de visitantes, jantar e pernoite na Reserva.

$\underline{\text { Dia } 03}-\rightarrow$ RPPN Seringal Triunfo $\rightarrow$ Cutias:

Manhã: Translado até o município de Cutias;

Tarde: Translado de lancha "voadeira" até o ponto exato da observação da pororoca;

Noite: Atividades culturais no centro de visitantes, jantar e pernoite no município de Cutias.

Dia 04 - Cutias (baixo Araguari) $\rightarrow$ RPPN Seringal Triunfo:

Manhã: Translado de volta até a RPPN;

Tarde: Banhos nas cachoeiras do rio Araguari;

Noite: Atividades culturais no centro de visitantes, jantar e pernoite na Reserva.

$\underline{\text { Dia } 05}$ - RPPN Seringal Triunfo $\rightarrow$ Macapá:

Manhã: Visita à áreas degradadas em recuperação, com o plantio de uma muda nativa pelo turista;

Tarde: Retorno à Macapá (Pousada Equinox ou embarque para a cidade de origem) e visita à APA Quilombo Curiaú, à Fortaleza de São José de Macapá e à Feira de Artesanato.

\footnotetext{
${ }^{13}$ Voadeira: barco de 6 metros com motor de 25 HP e capacidade para até 6 passageirossem carga.
} 


\section{2 - INFRA-ESTRUTURA NECESSÁRIA}

Nas últimas décadas, tem-se observado que o consumidor está mais atento para negócios que respeitam o meio ambiente. Assim, produtos que apresentam soluções tecnológicas socialmente e ambientalmente adequadas tendem a agregar valor à sua qualidade e conquistar maiores faixas de mercado. No caso do Turismo, um número crescente de viajantes tem procurado ambientes menos alterados, em busca de contato mais direto com paisagens naturais ou manifestações culturais representativas (WWF, 2003).

Contudo, a definição do tipo e localização de estruturas de hospedagem, alimentação, entretenimento e lazer, é determinante na elaboração dos roteiros a serem realizados na RPPN Seringal Triunfo. O estudo apresenta duas propostas de estruturas de hospedagem que deverão ser avaliadas de acordo com a demanda de turistas e com o resultado do Estudo de Impacto Ambiental da área. O importante é oferecer meios de hospedagem com os princípios de conforto mínimo, higiene, segurança e privacidade. As propostas de infra-estrutura a serem implantadas a partir deste estudo são:

- “Albergue de Selva”: como a hospedagem que já ocorre na propriedade, de construção rústica e são ideais para grupos entre seis e dez pessoas. As modalidades de hospedagem coletivas, como os Albergues da Juventude, famosos em todo o mundo, têm associados com o perfil do ecoturista nacional e internacional;

- Chalés: voltados para casais, estes não passarão de quatro unidades, seguindo a tendência das Ecopousadas, de construção rústica, tecnologias trdicionais e fontes alternativas de energia e água.

O estudo apresenta ainda duas propostas de estruturas de alimentação, entretenimento e lazer que também deverão ser avaliadas de acordo com a demanda de turistas e com o resultado do Estudo de Impacto Ambiental da área. As estruturas de alimentação, entretenimento e lazer desta proposta são as seguintes:

- Centro de Visitantes: é o ponto de referência para o visitante que terá acesso a documentos, livros e vídeos sobre a Reserva e a cultura do Amapá; também seria atividade compatível funcionar como espécie de entreposto, com a comercialização dos produtos desenvolvidos pelas comunidades vizinhas com matéria prima da região, como doces, compotas, biscoitos, cosméticos, artesanato, etc.;

- Refeitório Aberto: estará ligado ao albergue de selva com mesas e cadeiras , onde serão servidas as refeições para os visitantes. A proposta é que também sejam de construção rústica, tecnologias trdicionais e fontes alternativas de energia e água.

Contudo, outras estruturas podem ser inseridas a longo prazo como mecanismos para diminuir o impacto e melhorar as condições de acesso aos atrativos, como equipamentos facilitadores e de mobiliário ecoturístico (escadas, rampas, mirantes, bancos, guarda-corpos e abrigos). 


\section{3 - CRONOGRAMA DE IMPLANTAÇÃO}

A proposta de implantação do ecoturismo na RPPN Seringal Triunfo segue o roteiro abaixo, que é uma indicação geral dos passos a serem dados nos próximos cinco anos. Segue também as diretrizes de Joanesburgo (Rio+10) para o Turismo, em especial o artigo 41 que mostra que mais turismo equivale a menos pobreza. Assim, toda a mão-de-obra capacitada e utilizada nos serviços oferecidos pela Reserva será preferencialmente de nativos da comunidade Vila Paredão, próxima à hidroelétrica, ou dos Municípios de Ferreira Gomes e Porto Grande. Os potenciais parcerios e financiadores da RPPN Seringal Triunfo no estado são as organizações CEMA, CNS/AP, DETUR, EMBRAPA, IBAMA, SOPREN/AP, SEBRAE/AP, WWF-Brasil, Fundação 'O Boticario’, Funatura, ProEcotur/IBAMA, entre outros.

$\underline{\text { ANO } 1}$

- Capacitação: básica em ecoturismo; educação ambiental; gerenciamento; higiene; alimentação; receptivo; gerenciamento em hotelaria; primeiros socorros e guiagem.

- Estrutura: adequação de estruturas existentes ou construção de chalés para casal ou albergue coletivo; utilização de meios de transporte do proprietário ou alugados.

- Público-alvo da RPPN: mochileiros; pousadas e hotéis de Macapá; estudantes; pesquisadores; voluntários; ONGs e grupos de turistas voluntários.

ANO 2-3

- Capacitação: avançado em ecoturismo; alimentação; gerenciamento; receptivo; hotelaria; primeiros socorros e guiagem, incluindo interpretação de ambientes; treinamento para comercialização e operação; curso de inglês básico.

- Estrutura: construção de chalés para casal ou albergue coletivo; aquisição de meios de transporte apropriados; adequação e instrumentalização de estrutura da RPPN em Macapá.

- Público-alvo da RPPN: mochileiros; pousadas e hotéis de Macapá; estudantes; pesquisadores; voluntários; ONGs; grupos de turistas voluntários e ecoturista.

$\underline{\text { ANO 4-5 }}$

- Capacitação: reciclagem de cursos/treinamento já realizados e realização de novos cursos de acordo com necessidade da operação; curso de francês básico.

- Estrutura: construção de estruturas e ambientes para observação, como torres, passarelas suspensas e sevas; manutenção e paisagismo dos chalés/albergue.

- Público-alvo da RPPN: ecoturista; mochileiros; pousadas e hotéis de Macapá; estudantes; pesquisadores; voluntários e ONGs.

ANO 6-8

- Capacitação: reciclagem de cursos/treinamento já realizados e realização de novos cursos de acordo com necessidade da operação.

- Estrutura: manutenção e paisagismo de estruturas e ambiente.

- Público-alvo da RPPN: ecoturista com prioridade. 


\section{4 - RESULTADOS E DISCUSSÃO}

A criação da Reserva Seringal Triunfo veio ressarcir a Natureza da agressão com o impacto no ecossistema, causado pela inundação. A beleza das paisagens, a pujança da floresta, a tranqüilidade do grande lago, a emoção das cachoeiras criou opções conservacionistas que evitarão novas agressões e assegurarão ao homem meios de sobrevivência harmônica com a Natureza.

No entanto, a grande dimensão da propriedade e a impossibilidade de fiscalização da mesma, facilitou o acesso de alguns invasores, na década de 80, que praticaram pequenos desmatamentos nas áreas de melhor acesso, como o leito dos igarapés. Essa prática se fosse intensificada poderia iniciar um processo de açoreamento nos mesmos, interferindo no reservatório da Usina Hidroelétrica Coaracy Nunes. Assim, por se tratar de uma região onde a vegetação predominante é Floresta Ombrófila Densa, o projeto necessita indispensavelmente de um controle técnico florestal.

Com base no Decreto $\mathrm{n}^{0}$ 1.922, de 5 de junho de 1996, o proprietário estabeleceu em sua propriedade, todas as condições de um ambiente controlado e com sucesso de uma vida longa. Não visou com este trabalho uma forma de fins lucrativo ou promoção pessoal, somente o reconhecimento de uma tentativa a mais envolvendo o restabelecimento de um convívio mais harmonioso com a natureza. Certamente não podemos transformar o mundo, mas criarmos condições de uma vida racional, sem contarmos ainda que, com a preservação de espécies em vias de extinção, contaremos como resquícios para uma próxima geração. 


\section{6 - CONCLUSÃO}

A criação de uma RPPN Seringal Triunfo no local favoreceu em muito o ecossistema, já que é uma área de extrema importância, devido às dimensões bastante consideráveis. O represamento das águas do rio Araguari, com a conseqüente inundação das áreas próximas, na década de 60, causaram um grande impacto no ecossistema natural local, que hoje são verdadeiros laboratórios de pesquisas biológicas.

Ao se preservar a propriedade, devido a sua grande dimensão, são incalculáveis os benefícios para toda a população mundial, pois reservas com grande biodiversidade atuam na manutenção dos recursos visando a qualidade de vida das futuras gerações. É um passo avançado no projeto mundial de implantação de corredores de fauna na América. Preservar um ambiente equilibrado é a forma de envolver e desenvolver a população local de maneira participativa e democrática, tornando-a parceira da área protegida. A sustentabilidade dos projetos ambientais requer a efetiva participação da comunidade por meio dos conhecimentos que lhe são peculiares, aproveitando, assim, o capital de conhecimentos já acumulado.

Contudo, o objetivo do trabalho foi alcançado com a elaboração de um plano de ação que estabelece diretrizes e recomendações para viabilizar e implementar o ecoturismo na RPPN. A pesquisa propõe uma estratégia de uso responsável para a Reserva Seringal Triunfo e conclui que é nítido o potencial e a viabilidade de uma atividade ecoturística sustentável na RPPN, e que esta, ainda que sem os recursos financeiros para realizar um Plano de Manejo, tem cumprido seu papel na conservação do meio ambiente e que o ecoturismo tem se mostrado um importante caminho para o desenvolvimento social e econômico daquela região. 


\section{7 - BIBLIOGRAFIA CITADA}

ARRUDA, M. \& BOFF, L. Globalização: Desafios socioeconômicos, éticos e educativos. Rio de Janeiro: Vozes, 2000.

BOO, Elizabeth. O “Boom” do Ecoturismo: planejamento para o desenvolvimento e manejo. 2.ed. Tradução de: Peter Midkiff. Revisão de: Flávia Lacerda. [s.l]: WWF, 1994.

BOO, Elizabeth. "O planejamento ecoturístico para áreas protegidas” in Ecoturismo: um guia para planejamento e gestão. Lindberg, K. ; Hawkins D. E. (org.). São Paulo: Editora Senac São Paulo, 2002 (31-55).

BRASIL, MINISTÉRIO DO MEIO AMBIENTE E DA AMAZÔNIA LEGAL. Plano de Utilização da Reserva Extrativista do Rio Cajarí. Brasília: IBAMA, 1996

COSTA, C. M. R. (org.). Anais do I Seminário de Reservas Particulares de Minas Gerais. Publicação em CD-Rom. Belo Horizonte: Fundação Biodiversitas, 2001.

DENKER, A. F. M. Métodos e Técnicas de Pesquisa em Turismo. São Paulo: Futura, 1998.

EMBRATUR. Diretrizes para uma Política Nacional de Ecoturismo. Brasília: MINISTÉRIO DA INDÚSTRIA, DO COMÉRCIO E DO TURISMO: MINISTÉRIO DO MEIO AMBIENTE E DA AMAZÔNIA LEGAL, 1994. Disponível em www.geocities.com/yosemite/rapids/4055/textos.html. Consultado em 04 de outubro de 2002.

FENNELL, David A. Ecoturismo uma introdução. David A. Fennell; tradução de Inês Lohbauer. - São Paulo: Contexto, 2002. - (Coleção Turismo Contexto).

FILOCREÃO, A. S. M. (org.). Sócio-Economia da Reserva Extrativista do Rio CajaríAP. Macapá: IBAMA, 1993.

FUNDAÇÃO BIODIVERSITAS. Programa de Unidades de Conservação. Disponível em: www.bdt.org.br/biodiversitas/uc. Consultado em 11de março de 2003.

GOVERNO DO ESTADO DO AMAPÁ, SECRETARIA DE ESTADO DO PlaneJAMENTO E COORDENAÇÃO GERAL. Amapá Programa de Desenvolvimento Sustentável. Macapá: Seplan, 1995.

GRUPO NATIVA, CENTRO NACIONAL PARA O DESENVOLVIMENTO DAS POPULAÇÕES TRADICIONAIS, MMA, SCA, PPG7. Inventário e diagnóstico Reserva Extrativista do Rio Cajarí. Goiânia: 1998.

GRUPO NATIVA, CENTRO NACIONAL PARA O DESENVOLVIMENTO DAS POPULAÇÕES TRADICIONAIS, MMA, SCA, PPG7. Planejamento Geral do Programa de Desenvolvimento de Ecoturismo em Reservas Extrativistas. Goiânia: 1999.

GRUPO NATIVA, CENTRO NACIONAL PARA O DESENVOLVIMENTO DAS POPUlAÇÕES TRADICIONAIS, MMA, SCA, PPG7. Plano Executivo do Programa de Desenvolvimento de Ecoturismo em Reservas Extrativistas. Goiânia: 1999.

IBAMA. Roteiro Metodológico de Planejamento. Brasília: MMA/IBAMA, 2002.

IBAMA. Manual Informativo do Programa Reservas Particulares do Patrimônio Natural. Projeto IBAMA/RPPN - FUNBIO. Brasília: IBAMA, 1999.

LINDBERG, K. ; HAWKINS D. E. (org.) Ecoturismo: um guia para planejamento e gestão. São Paulo: Editora Senac São Paulo, 2002.

MESQUITA, C. A. B. Caracterización de las reservas naturales privadas en América Latina. Tesis Mag. Sc. Turrialba, Costa Rica: CATIE, 1999. 
MESQUITA, C. A. B. ; LEOPOLDINO, F. S. Incentivando e Apoiando a Criação, Manejo e Integração entre Reservas Particulares do Patrimônio Natural (RPPNs) In: Anais do III Congresso Brasileiro de Unidades de Conservação. Fortaleza: Rede Nacional Pró-Unidades de Conservação: Fundação O Boticário de Proteçnao à Natureza: associação Caatinga, 2002. v1.

MMA. (2003a) Unidades de Conservação. Disponível no site: www.mma.gov.br/port/sbf/dap/apconse.html. Consultado em 11 de março de 2003.

MMA. (2003b) Para que Parques? Disponível no site: www.mma.gov.br/port/sbf/dap/apbpparq.html. Consultado em 11 de março de 2003.

MMA. (2003c) Histórico das Áreas Protegidas. Disponível no site: www.mma.gov.br/port/sbf/dap/apbhist.html. Consultado em 11 de março de 2003.

MITRAUD, S. F. (org.). Manual de Ecoturismo de Base Comunitária: ferramentas para um planejamento responsável. Brasília, DF: WWF-Brasil, 2003.

MITRAUD, S. F. (Coordenação). Uso Recreativo do Parque Nacional Marinho de Fernando de Noronha. Brasília, DF: WWF-Brasil, Vol 8, 2001.

MILANO, Miguel Serediuk; BERNARDES, Ângela Tresinari; FERREIRA, M. Lourdes. Mitos no manejo de unidades de conservação no Brasil, ou a verdadeira ameaça. In: Anais do II Congresso Brasileiro de Unidades de Conservação. Campo Grande: Rede Nacional PróUnidades de Conservação: Fundação O Boticário de Proteçnao à Natureza: 2000. v. 1, p. 11-25.

MOURÃO, Roberto M. F. Ecoturismo e Turismo Especializado: conceitos e critérios. Versão 1.0 Programa MPE. FUNBIO 09/01. Consultado em: www.ecobrasil.org.br. em 17 de novembro de 2002

MOURÃO SÁ, L. A Educação Como Instrumento De Um Processo Democrático De Gestão Ambiental, no prelo, 2001.

PADUA, S. M. Planejamento, Processo, Produto.

PEREIRA, Célia. A Experiência do IBAMA na Criação de Reservas Particulares do Patrimônio Natural (RPPNs). In: Anais do III Congresso Brasileiro de Unidades de Conservação. Fortaleza: Rede Nacional Pró-Unidades de Conservação: Fundação O Boticário de Proteçnao à Natureza: associação Caatinga, 2002. v. 1.

ROBERTSON, R. "Valores e globalização: comunitarismo e globalidade”, in Pluralismo Cultural, Identidade e Globalização, Mendes, C. (coord.) e Soares, Luiz E. (ed.), Rio de Janeiro: Record, 2001 (76-102).

ROCHA, Marta Maria S. Projeto de Criação da RPPN Seringal Triunfo: Projeto Aricary, Amapá: 1997.

SEABRA, G. Ecos do turismo: O Turismo ecológico em áreas protegidas. Campinas, SP: Papirus Editora, 2001. - (Coleção Turismo).

TIBONI, C. G. R. Estatística Básica para o Curso de Turismo. São Paulo: Atlas, 2002. 


\title{
8 - ANEXOS
}

\section{1 - LEGISLAÇÃO}

\author{
SISTEMA NACIONAL DE UNIDADES \\ DE CONSERVAÇÃO DA NATUREZA - SNUC \\ LEI N ${ }^{\circ}$ 9.985, DE 18 DE JULHO DE 2000
}

Art. 21 - A Reserva Particular do Patrimônio Natural é uma área privada, gravada com perpetuidade, com o objetivo de conservar a diversidade biológica.

$\S 1$. O gravame de que trata este artigo constará de termo de compromisso assinado perante o órgão ambiental, que verificará a existência de interesse público, e será averbado à margem da inscrição no Registro Público de Imóveis.

$\S 2$. Só poderá ser permitida, na Reserva Particular do Patrimônio Natural, conforme se dispuser em regulamento:

I - a pesquisa científica;

II - a visitação com objetivos turísticos, recreativos e educacionais.

$\S$ 3. Os órgãos integrantes do SNUC, sempre que possível e oportuno, prestarão orientação técnica e científica ao proprietário de Reserva Particular do Patrimônio Natural para elaboração de um Plano de Manejo ou de Proteção e Gestão da unidade.

\section{DECRETO Nº 1.922, DE 5 DE JUNHO DE 1996}

Dispõe sobre reconhecimento das Reservas Particulares do Patrimônio Natural, e dá outras providências.

O Presidente da República, no uso das atribuições que lhe confere o art. 84, inciso IV e art. 225 da Constituição em tendo em vista o disposto no código Floresta-Lei n. 4.771, de 15 de setembro de 1965, e na Lei n. 8.171, de 17 de janeiro de 1991.

DECRETA:

Art. 1 - Reserva Particular do Patrimônio Natural - RPPN é área de domínio privado a ser especialmente protegida, por iniciativa de seu proprietário, mediante reconhecimento do Poder Público, por ser considerada de relevante importância pela sua biodiversidade, ou pelo seu aspecto paisagístico, ou ainda por suas características ambientais que justifiquem ações de recuperação.

Art. 2 - As RPPN's terão por objetivo a proteção dos recursos ambientais representativos da região.

Art. 3 - As RPPN's poderão ser utilizadas para o desenvolvimento de atividades de cunho científico, cultural, educacional, recreativo e de lazer, observado o objetivo estabelecido no artigo anterior. 
$\S 1$. As atividades previstas neste artigo deverão ser autorizadas ou licenciadas pelo órgão responsável pelo reconhecimento da RPPN e executadas de modo a não comprometer o equilíbrio ecológico ou colocar em perigo a sobrevivência das populações ali existentes, observada a capacidade de suporte da área, a ser prevista no plano de utilização que trata o Art. 8. Inciso II deste Decreto.

$\S 2$. Somente será permitido no interior das RPPNs a realização de obras e infra-estrutura que sejam compatíveis e necessárias às atividades previstas no caput deste Artigo.

Art. 4 - A área será reconhecida como Reserva Particular ao Patrimônio natural por iniciativa de seu proprietário e mediante portaria do Instituto Brasileiro do meio Ambiente e dos Recursos Naturais Renováveis - IBAMA, na esfera federal.

Art. 5 - O Proprietário interessado em ter reconhecido seu imóvel, integral ou parcialmente, como RPPN, deverá requerer junto à Superintendência do IBAMA na Unidade da Federação onde estiver situado o imóvel ou junto ao Órgão Estadual do Meio Ambiente - OEMA, acompanhado de cópias autenticadas dos seguintes documentos:

I - título de domínio, com matrícula no cartório de registro de imóveis competente;

II - cédula de identidade do proprietário, quando se tratar de pessoa física;

III - ato de designação de representante quando se tratar de pessoa jurídica;

IV - quitação do Imposto sobre a Propriedade Territorial Rural - ITR;

V - plantas de situação indicando os limites, os confrontantes, a área a ser reconhecida e a localização da propriedade o município ou região.

Parágrafo único. Serão prioritariamente apreciados pelo órgão responsável pelo reconhecimento os requerimentos referentes aos imóveis contíguos às unidades de conservação ou a áreas cujas características devam ser preservadas no interesse do patrimônio natural do país.

Art. 6 - O Órgão responsável pelo reconhecimento da RPPN, no prazo de sessenta dias, contados da data de protocolização do documento, deverá:

I - emitir laudo de vistoria do imóvel, com descrição da área, compreendendo a tipologia vegetal, a hidrologia, os atributos naturais que se destacam, o estado de conservação da área proposta, indicando as eventuais pressões potencialmente degradadoras do ambiente, relacionando as principais atividades desenvolvidas na propriedade;

II - emitir parecer, incluindo análise da documentação apresentada e, se favorável, solicitar ao proprietário providências no sentido de firmar, em duas vias, o termo de compromisso, de acordo com o modelo anexo a este Decreto.

III - homologar o pedido por meio de autoridade competente;

IV - publicar no Diário Oficial ato de reconhecimento da área como RPPN;

$\S 1$ - Após a publicação do ato de reconhecimento, o proprietário deverá, no prazo de sessenta dias, promover a averbação do termo de compromisso, a que se refere o inciso II do art. 6 deste Decreto, no Cartório de registro de Imóveis competente, gravando a área do imóvel reconhecida como Reserva em caráter perpétuo, nos termos do que dispõe o art. 6 da Lei 4.771/65, a fim de ser emitido o título de reconhecimento definitivo.

§ 2 - O descumprimento, do proprietário, da obrigação referida no parágrafo anterior importará na revogação da portaria de reconhecimento. 
Art. 7 - Será concedida, à RPPN, pelas autoridades públicas competentes, proteção assegurada pela legislação em vigor às unidades de conservação de uso indireto, sem prejuízo do direito de propriedade, que deverá ser exercido por seu titular, na defesa da Reserva, sob orientação com apoio do órgão competente.

Parágrafo único. No exercício das atividades de fiscalização, monitoramento e orientação às RPPNs, o órgão responsável pelo reconhecimento deverá ser apoiado pelos órgãos públicos, que atuam na região, podendo também obter a colaboração de entidades privadas, mediante convênios, com a anuência do proprietário do imóvel.

Art. 8 - Caberá ao proprietário do imóvel:

I - assegura a manutenção dos atributos ambientai da RPPN e promover sua divulgação na região, mediante, inclusive, a colocação de placas nas vias de acesso e nos limites da área, advertindo terceiros quanto a proibição de desmatamentos, queimadas, caça, pesca, apanha, captura de animais ou quaisquer outros atos que possam afetar o meio ambiente;

II - submeter à aprovação do órgão responsável pelo reconhecimento o zoneamento e o plano de utilização da Reserva, em consonância com o previsto nos § 1 e $\S 2$ do Art. 3, deste Decreto;

III - encaminhar, anualmente e sempre que solicitado, ao órgão responsável pelo reconhecimento, relatório da situação da Reserva e das atividades desenvolvidas.

Parágrafo único - Para o cumprimento do disposto neste artigo o proprietário poderá solicitar a cooperação de entidades ambientalistas devidamente credenciadas pelo Cadastro Nacional de Entidades Ambientalistas - CNEA, do Conselho Nacional do Meio Ambiente - CONAMA.

Art. 9 - O órgão responsável pelo reconhecimento, sempre que julgar necessário, poderá realizar vistoria na Reserva ou credenciar universidades ou entidades ambientalistas com a finalidade de verificar se a área está sendo manejada de acordo com os objetivos estabelecidos no plano de utilização.

Art. 10 - Os danos ou irregularidades praticadas à RPPN serão objetos de notificação a ser efetuadas pelo órgão responsável pelo reconhecimento, ao proprietário, que deverá manifestar-se no prazo a ser estabelecido.

Parágrafo único. Caso seja constatada a prática de infração ao disposto neste Decreto, o infrator estará sujeito às sanções administrativas previstas na legislação vigente, sem prejuízo da responsabilidade civil ou penal.

Art. 11 - O proprietário poderá requerer ao Instituto Nacional de Colonização e Reforma Agrária - INCRA, a isenção do Imposto sobre a Propriedade Territorial Rural-ITR, para a área reconhecida como Reserva Particular do Patrimônio Natural, conforme prevê o parágrafo único do art. 104, da Lei n. 8.171/91.

Art. 12 - Os projetos necessários à implantação e gestão das RPPNs reconhecidas ou certificadas pelo IBAMA deverão ter prioridade na análise de concessão de recursos ao Fundo Nacional do Meio Ambiente - FNMA.

Art. 13 - A propriedade que contiver RPPN no seu perímetro terá preferência na análise do pedido de concessão de crédito agrícola, pelas instituições oficiais de crédito. 
Art. 14 - Os incentivos de que tratam os Arts. 11, 12 e 13 deste Decreto somente poderão ser utilizados para as RPPNs reconhecidas pelo Poder Público Estadual ou Municipal, mediante certificação do IBAMA, que comprovará o cumprimento dos dispositivos deste Decreto.

Art. 15 - Caberá ao IBAMA fiscalizar o cumprimento das determinações constantes deste

Decreto, e ainda solicitar o cancelamento dos incentivos concedidos, caso haja inobservância das mesmas.

Art. 16 - O IBAMA expedirá os atos normativos complementares ao cumprimento deste Decreto.

Art. 17 - Este Decreto entra em vigor na data de sua publicação.

Art. 18 - Fica revogado o Decreto n. 98.914, de 31 de janeiro de 1990.

Brasília, 5 de junho de 1996. 175 da Independência e 108 da República

FERNANDO HENRIQUE CARDOSO

Gustavo Krause

Publicado no DOU nº 109, Seç. I, pag. 10024, de 07/06/1996. 
8.2 - MAPAS

- MAPA 1 - Unidades de Conservação do Amapá;

- MAPA 2 - BR 156 Ferreira Gomes;

- MAPA 3 - RPPN Seringal Triunfo;

- MAPA 4 - Detalhe Fazenda e RPPN;

- MAPA 5 - Mapa de Fotografias. 


\section{Cadastro}

\section{Região}

Tipo de atrativo

\begin{tabular}{|ll|}
\hline Águas & Mirantes \\
Cavernas & Hist / Cult / Espiritualistas
\end{tabular}

Subtipo

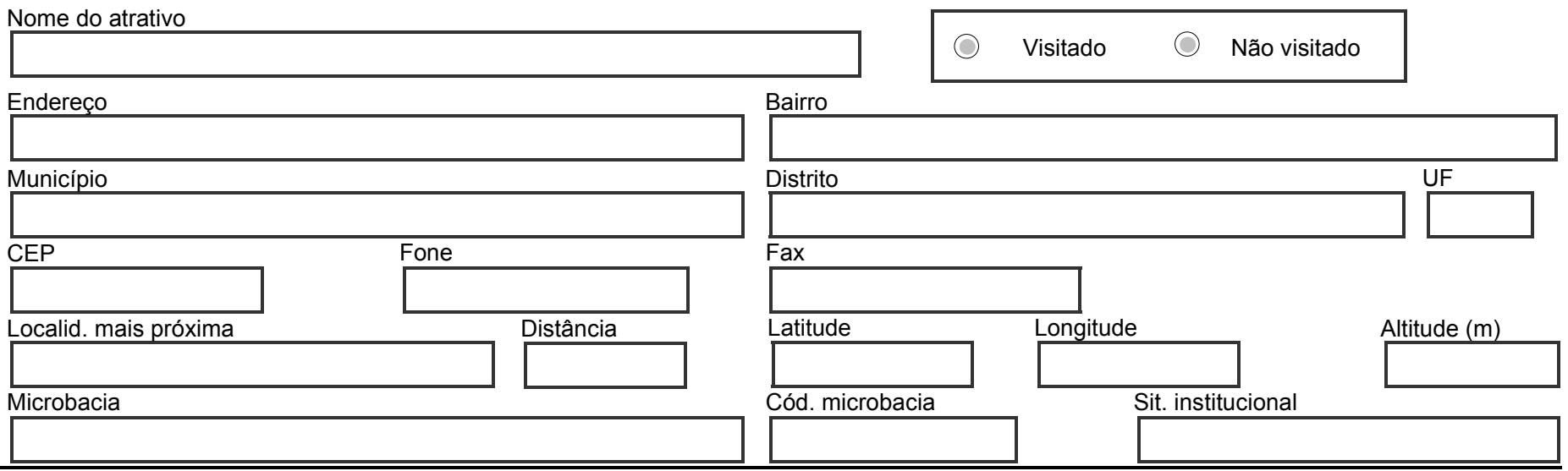

\section{Pessoal}
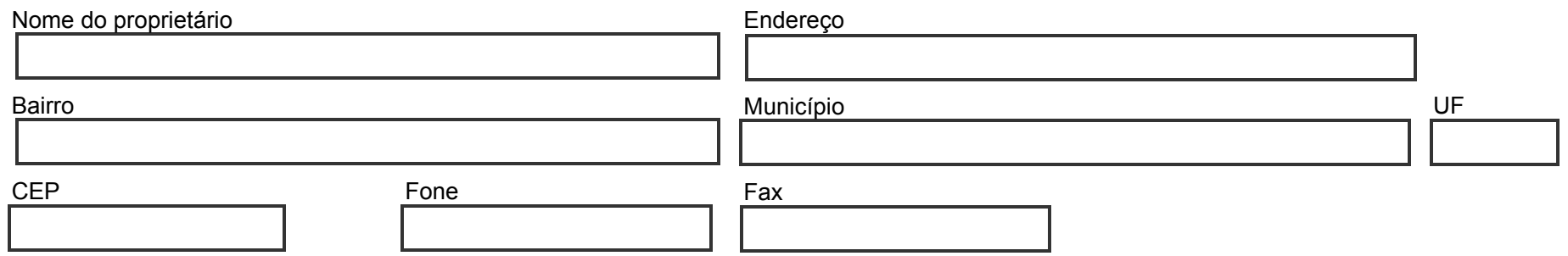

Reside no município ?
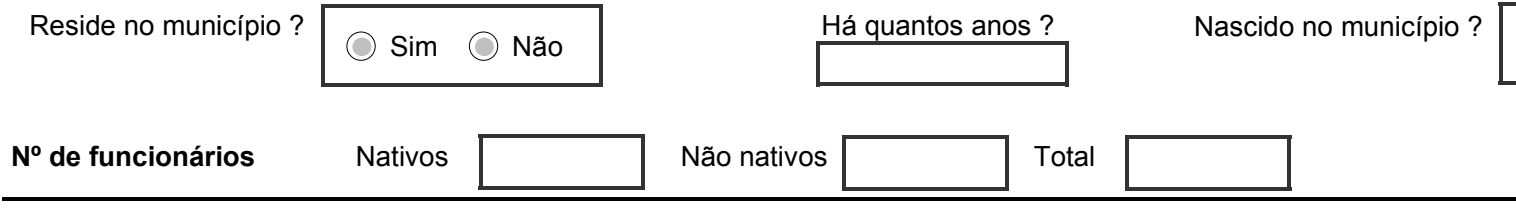

Nascido no município ?

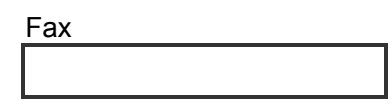

\section{Acessos}

\begin{tabular}{|c|c|c|c|c|c|c|}
\hline Rodoviário & $\begin{array}{l}\text { Pavimentado } \\
\mathrm{km}\end{array}$ & $\begin{array}{l}\text { Não pavimentado } \\
\mathrm{km}\end{array}$ & Condições & () Bom & Regular & (1) Ruim \\
\hline$\underline{\text { Hidroviário }}$ & $\mathrm{km}$ & $\square$ Lago & \multicolumn{2}{|c|}{$\square$ Embarcadouro } & & \\
\hline Navegação & Grande porte & (1) Pequeno porte & mo & arcadourc & & \\
\hline
\end{tabular}

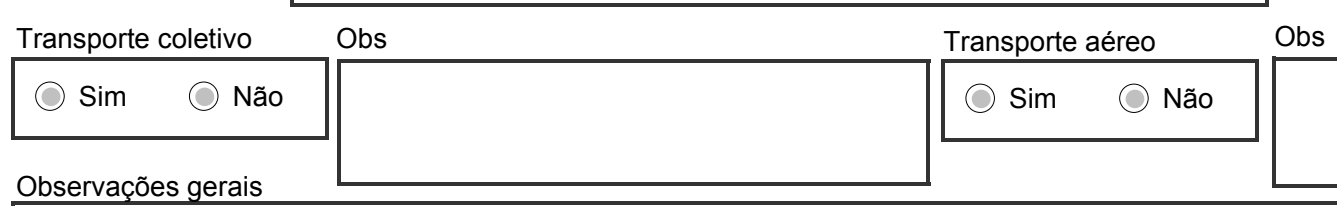

Observações gerais

Trilhas internas $\quad \mathrm{km} \quad$ Interpretativa?

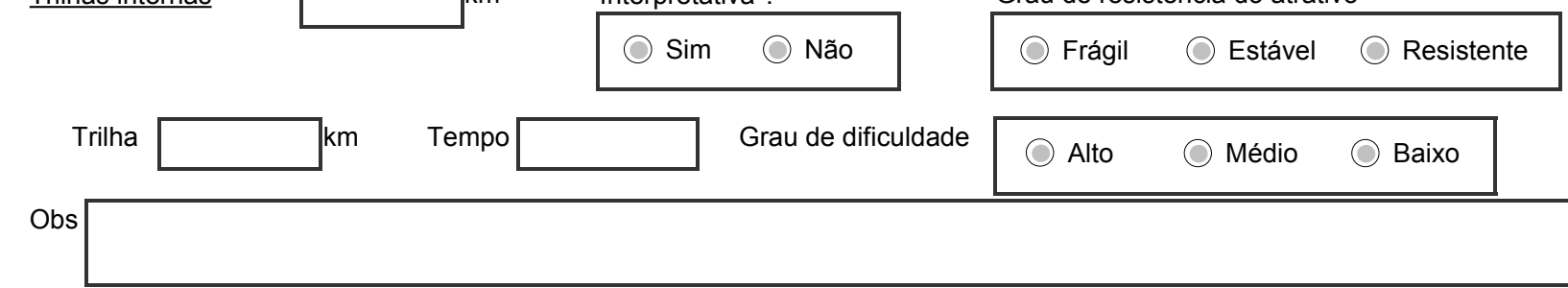




\section{Visitacão}

Acessabilidade ao atrativo
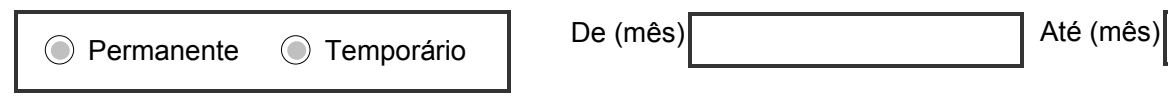

Tempo necessário para conhecer

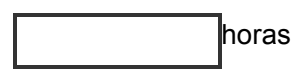

$N^{\circ}$ turistas/guia

Capacidade de carga

\begin{tabular}{|c|c|c|c|c|c|}
\hline \multicolumn{3}{|c|}{ Estação chuvosa } & \multicolumn{3}{|c|}{ Estação seca } \\
\hline & Trilha & Atrativo & & Trilha & Atrativo \\
\hline $\mathrm{N}^{\circ}$ pessoas & & & $\mathrm{N}^{\circ}$ pessoas & & \\
\hline$N^{\circ}$ grupos & & & $N^{\circ}$ grupos & & \\
\hline Capac. final & & pessoas & Capac. final & & pessoas \\
\hline
\end{tabular}

\begin{tabular}{l}
$\begin{array}{l}\text { Risco de } \\
\text { acidentes }\end{array}$ Alto $\bigcirc$ Médio $\bigcirc$ Baixo \\
\hline
\end{tabular}

$\begin{array}{lllll}\text { Meses de maior visitação } & \square \text { Janeiro } \quad \square \text { Fevereiro } \quad \square \text { Março } \quad \square \text { Abril } \quad \square \text { Maio } & \square \text { Junho } \\ & \square \text { Julho } \quad \square \text { Agosto } \quad \square \text { Setembro } \quad \square \text { Outubro } \square \text { Novembro } \quad \square \text { Dezembro }\end{array}$

$\underline{N^{\circ} \text { médio de visitantes/dia }}$

$\underline{\text { Horário de funcionamento }}$

Alta temporada/feriados

Alta temporada/feriados
Baixa temporada

Baixa temporada
$\underline{\text { Dias }}$
$\square$ Seg
$\square$ Ter
$\square$ Qua
$\square$ Qui
$\square$ Sex $\square$ Sab
Dom

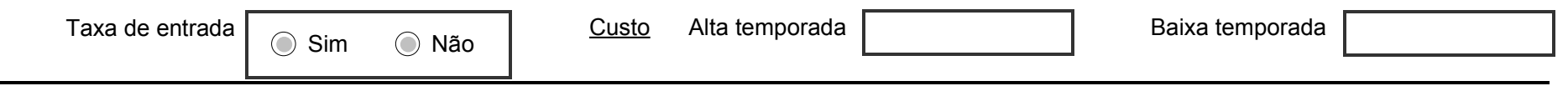

\section{Estrutura}

Infra-estrutura $\quad \square$ Sanitários $\square$ Esgoto Público $\quad \square$ Fossa Séptica $\quad \square$ Fossa Negra $\quad \square$ Escoamento
$\square$ Portaria $\quad \square$ Sinalização $\quad \square$ Sistema de Trilhas $\square$ Lixeiras

\begin{tabular}{|c|c|c|c|c|c|c|}
\hline \multirow{2}{*}{$\begin{array}{l}\text { Estrutura } \\
\text { física }\end{array}$} & Rebocado & & \multirow[b]{2}{*}{ Revestimento } & \multirow[b]{2}{*}{$\begin{array}{l}\square \text { Cimento queimado } \\
\square \text { Cimento }\end{array}$} & \multirow[b]{2}{*}{$\begin{array}{l}\square \text { Chapisco } \\
\square \text { Tinta }\end{array}$} & \multirow[b]{2}{*}{$\begin{array}{l}\square \text { Madeira } \\
\square \text { Outros }\end{array}$} \\
\hline & Sim & (C) Não & & & & \\
\hline
\end{tabular}

$\underline{\text { Sanitários }} \begin{aligned} & \text { Rebocado } \\ & \text { Sim Não }\end{aligned}$

Revestimento

$\begin{array}{cc}\text { Telhas } & \square \text { Ceramica } \square \text { Amianto } \square \text { Cimento } \\ \square \text { Zinco } & \square \text { Palha } \square \text { NDA }\end{array}$
$\square$ Azulejo $\square$ Cimento queimado
$\square$ Chapisco
$\square$ Madeira
$\square$ Cimento
$\square$ Tinta
$\square$ Outros

Aparência geral

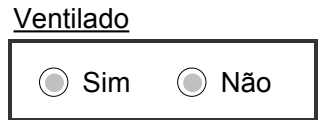

Destino do lixo $\square$ Coleta municipal $\square$ Separa $\square$ Leva p/ cidade $\square$ Queima

$\square$ Enterra $\square$ Recicla $\square$ Alimenta animal $\square$ Compostagem $\square$ NDA 
ATRATIVOS TURÍSTICOS

Data Hora Pesquisador

Cód. formulário Cód. base

\section{Impactos}

\begin{tabular}{r|cccc|} 
Impactantes & Alto & Médio & Baixo & Nenhum \\
\cline { 2 - 5 } Turismo & $\square$ & $\square$ & $\square$ & $\square$ \\
\cline { 2 - 5 } Agricultura & $\square$ & $\square$ & $\square$ & $\square$ \\
\cline { 2 - 5 } Pecuária & $\square$ & $\square$ & $\square$ & $\square$ \\
\cline { 2 - 4 } Obras & $\square$ & $\square$ & $\square$ & $\square$ \\
\cline { 2 - 4 } Acessos & $\square$ & $\square$ & $\square$ & $\square$ \\
\hline & $\square$ & $\square$ & $\square$ & $\square$
\end{tabular}

\begin{tabular}{c|cccc|} 
Impactados & Alto & Médio & Baixo & Nenhum \\
\cline { 2 - 5 } Água & $\square$ & $\square$ & $\square$ & $\square$ \\
\cline { 2 - 5 } Vegetação & $\square$ & $\square$ & $\square$ & $\square$ \\
\cline { 2 - 5 } Paisagem & $\square$ & $\square$ & $\square$ & $\square$ \\
\cline { 2 - 5 } Cultura Local & $\square$ & $\square$ & $\square$ & $\square$ \\
\cline { 2 - 4 } Mata Ciliar & $\square$ & $\square$ & $\square$ & $\square$ \\
\cline { 2 - 4 } & $\square$ & $\square$ & $\square$ & $\square$ \\
\hline
\end{tabular}




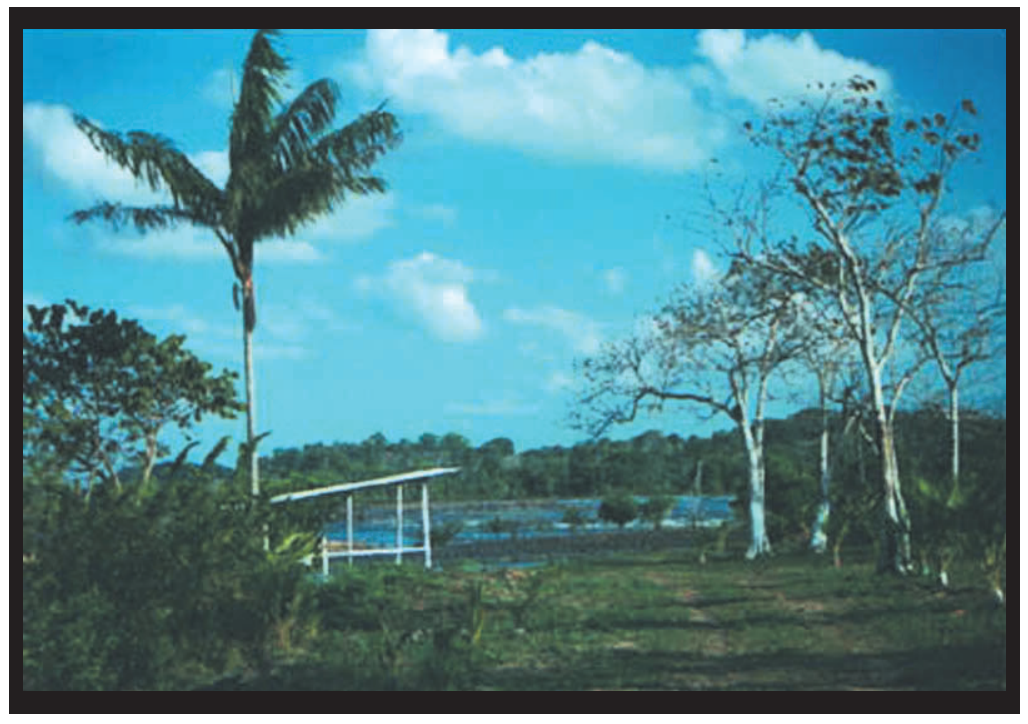

FIGURA 16. Prainha

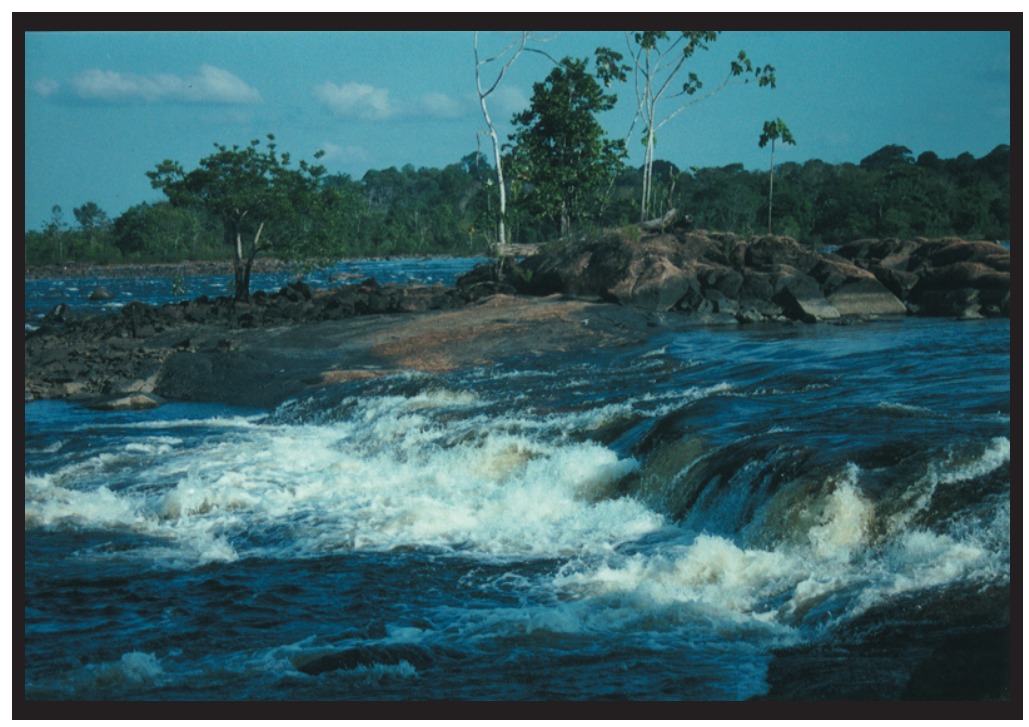

FIGURA 17. Corredeiras na Prainha

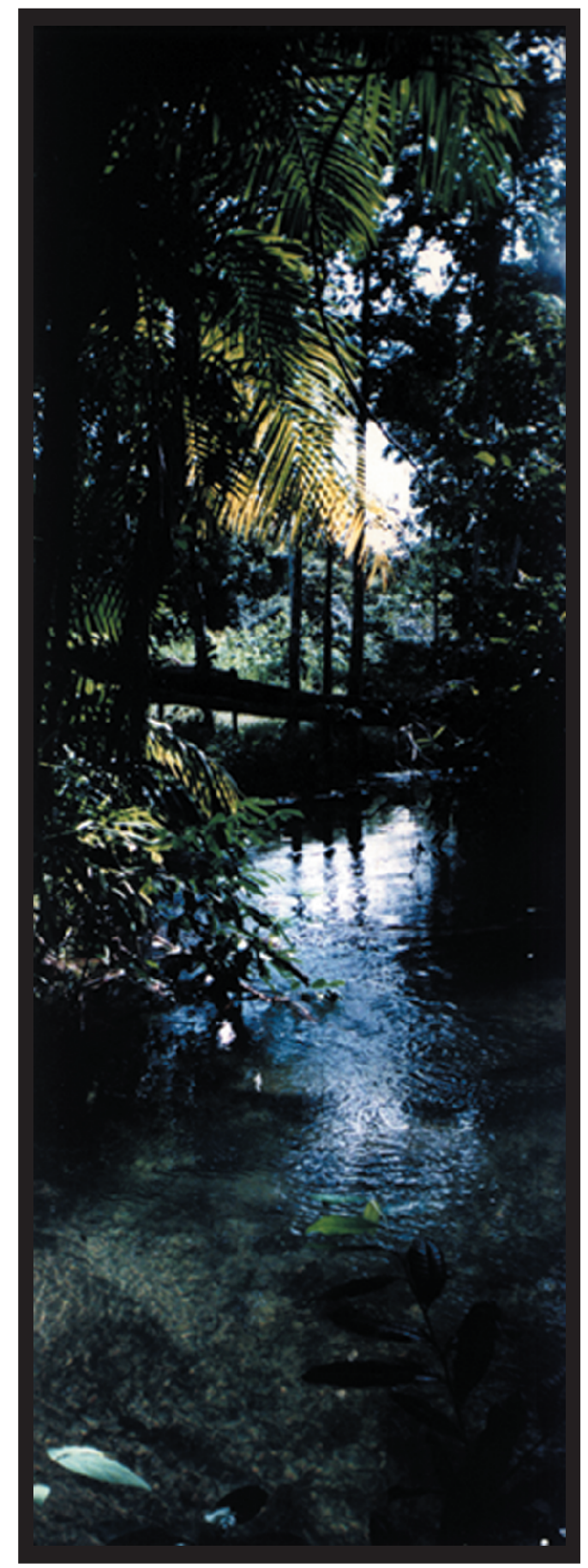

FIGURA 18. Igarapé Traíra 


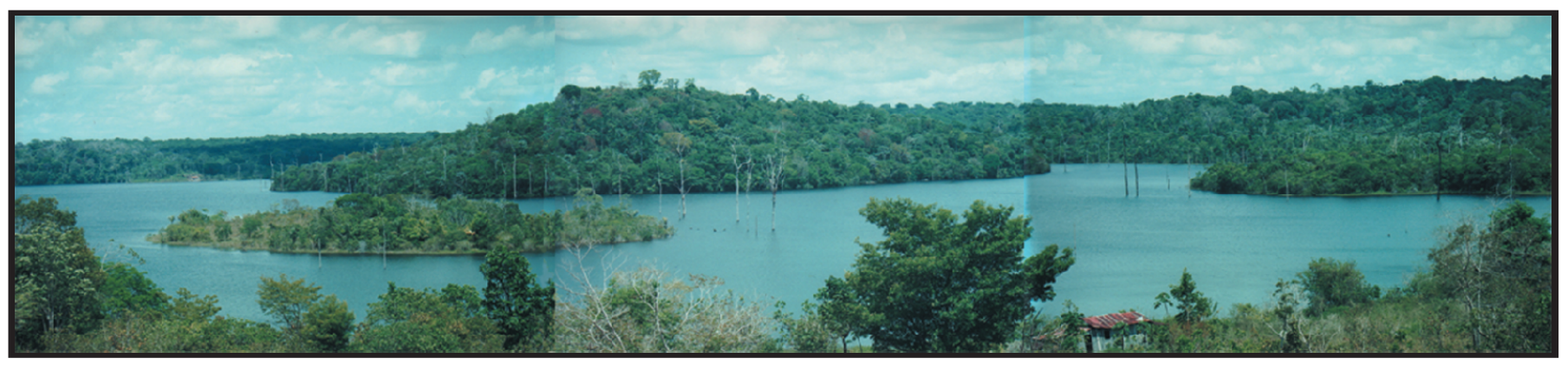

FIGURA 13. Área alagada na construção da Represa e RPPN ao fundo

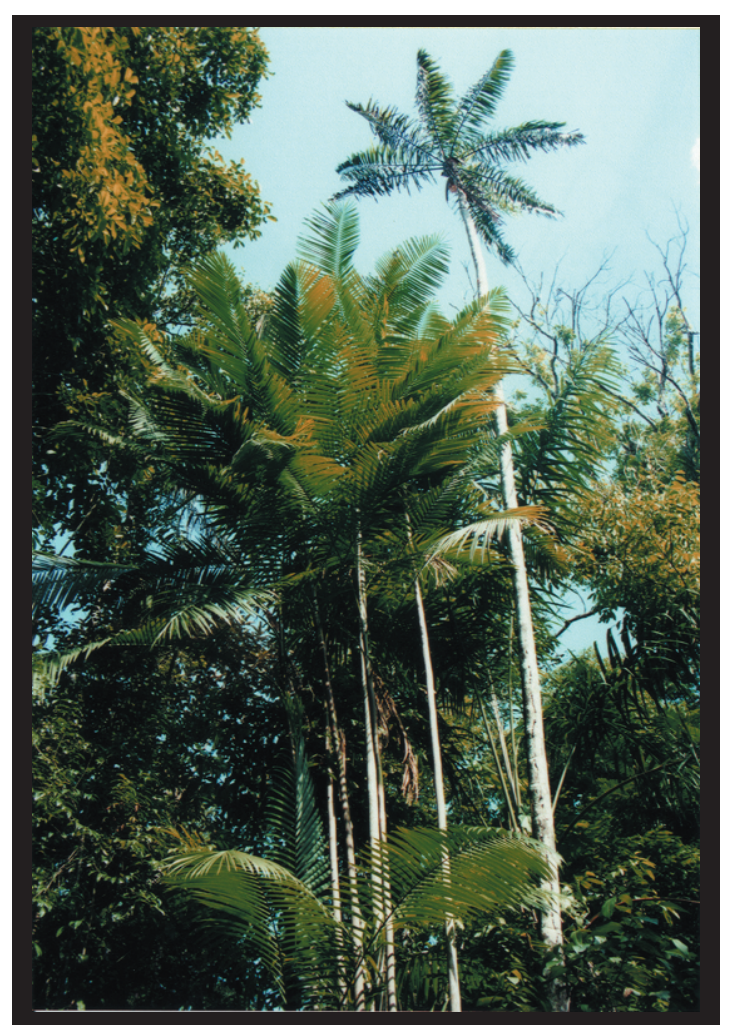

FIGURA 14. Açaí

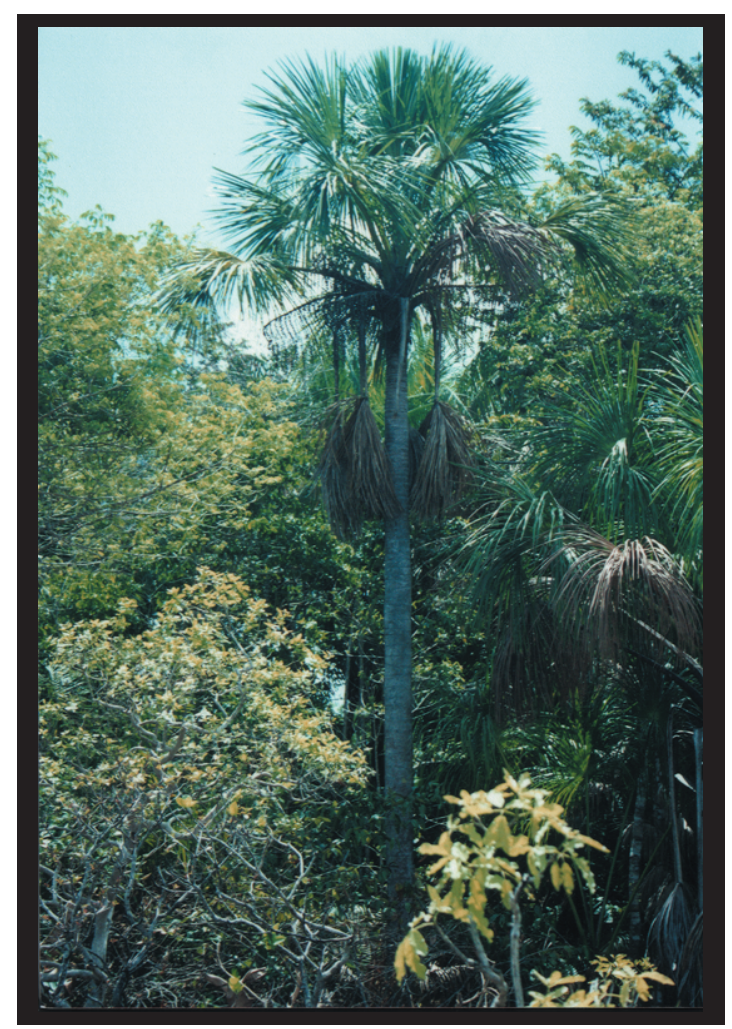

FIGURA 15. Buriti 


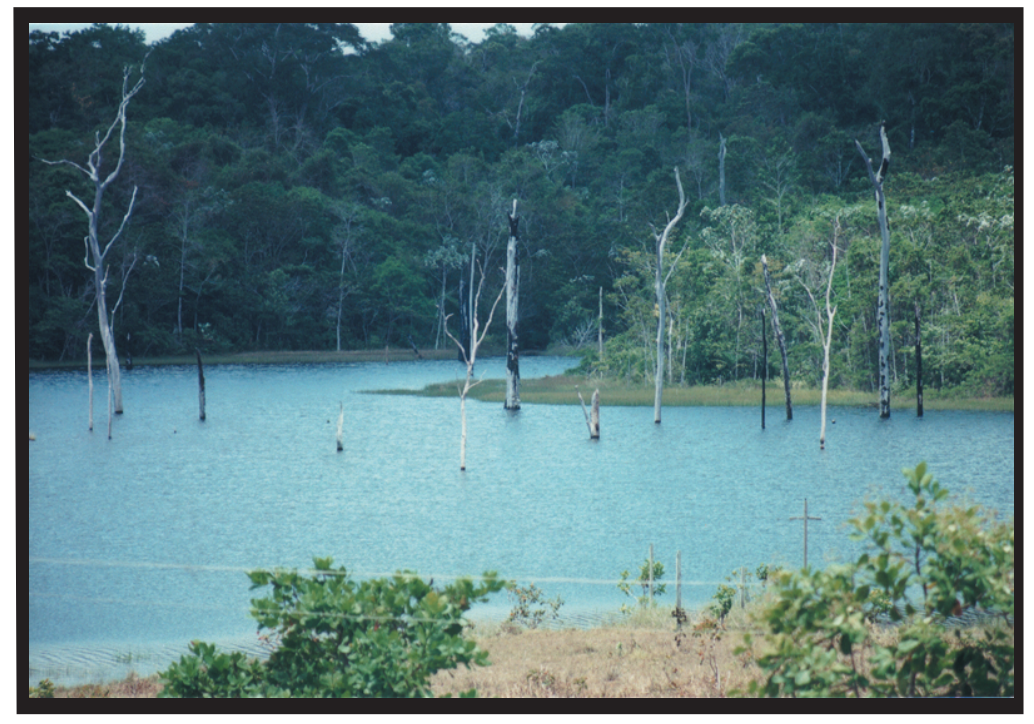

FIGURA 10. Área alagada na construção da Represa

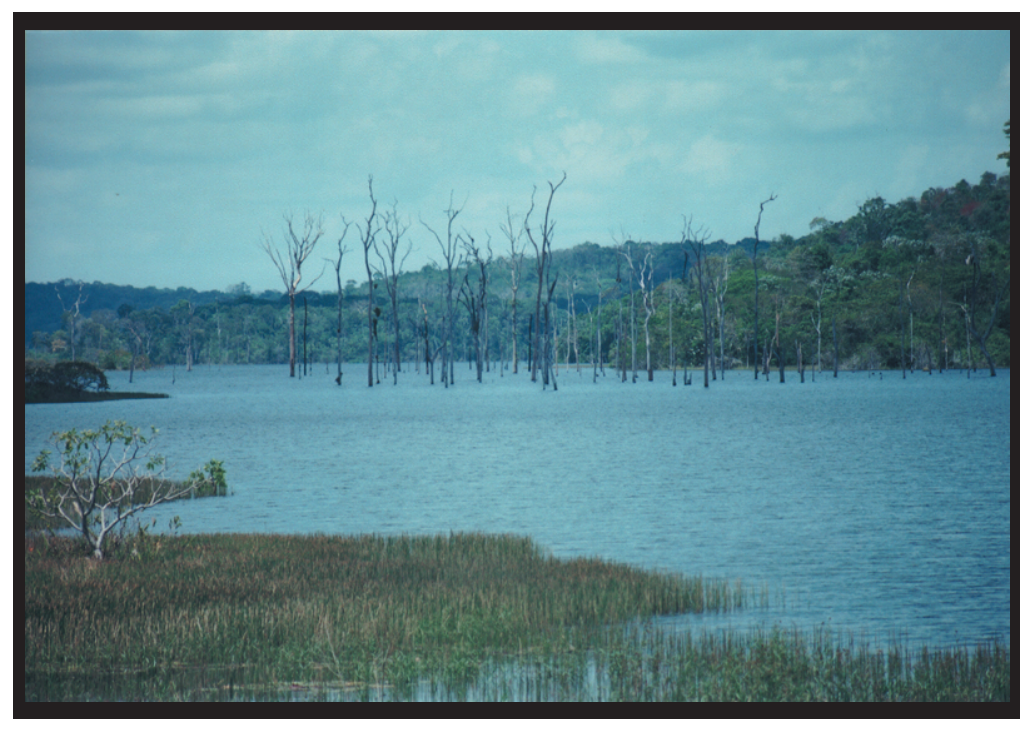

FIGURA 11. Área alagada na construção da Represa

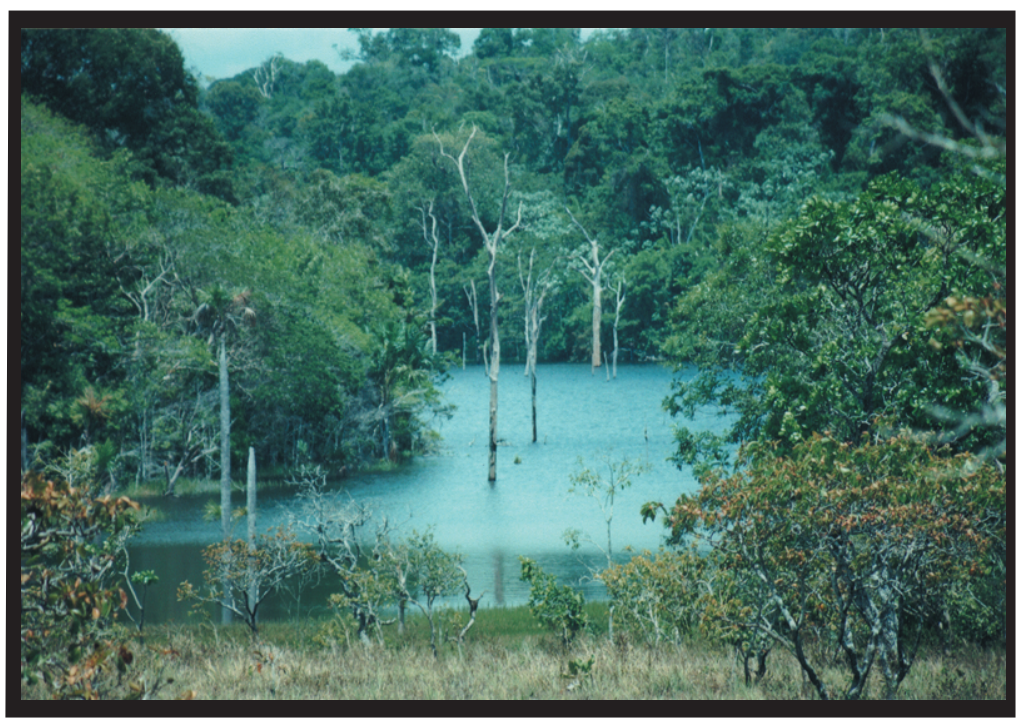

FIGURA 12. Área alagada na construção da Represa 


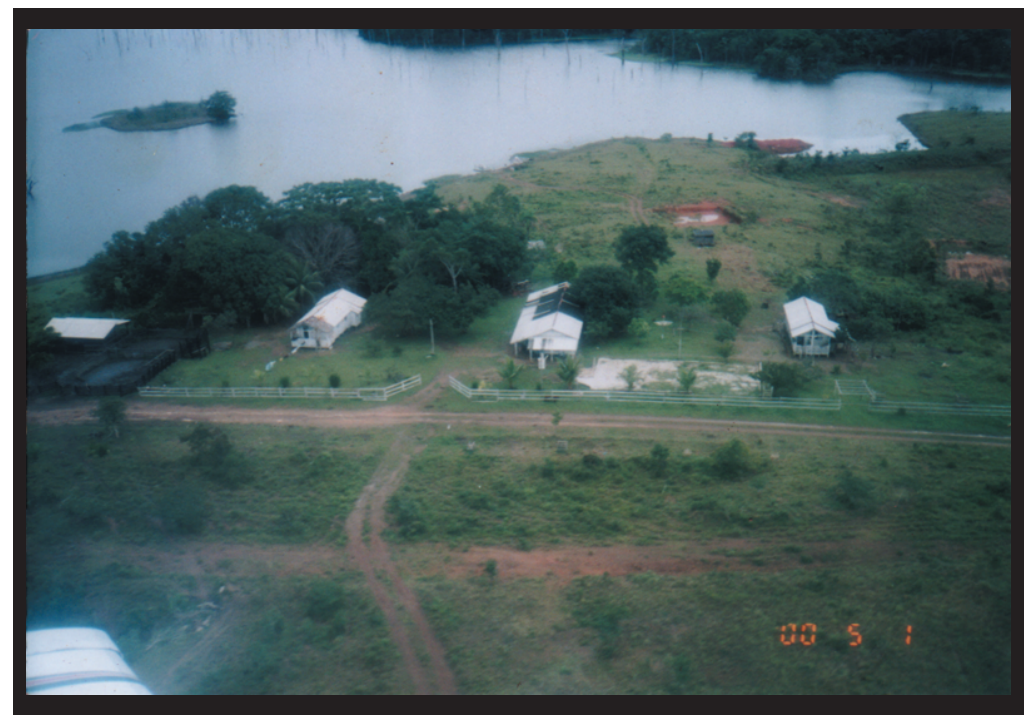

FIGURA 7. Vista aérea da Sede da Fazenda

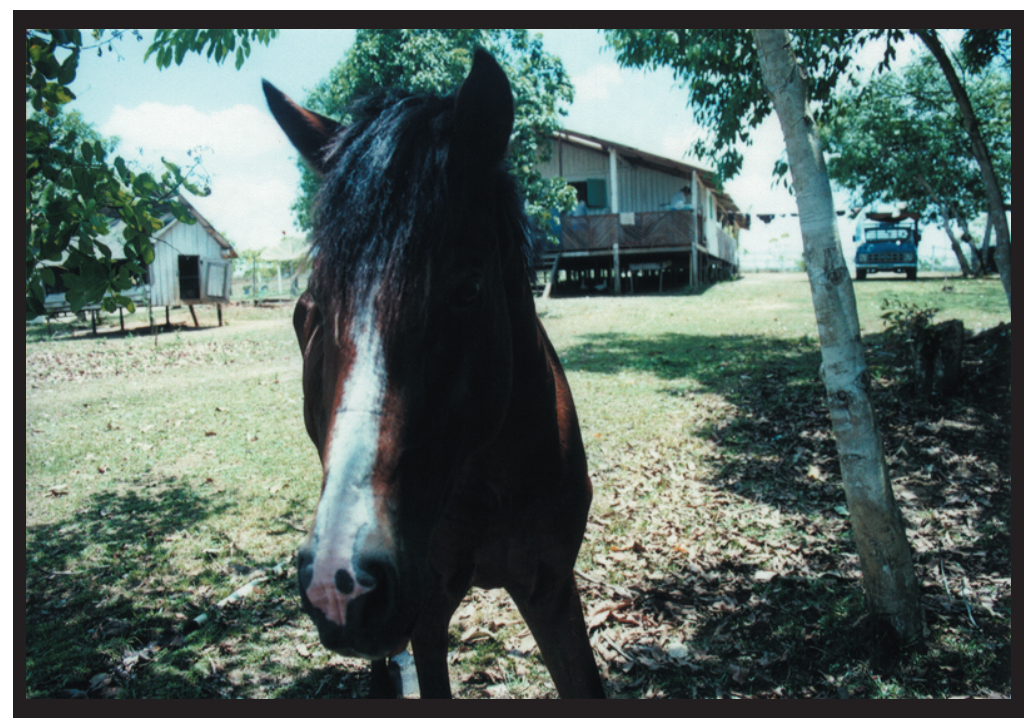

FIGURA 8. Vista Externa da Sede da Fazenda

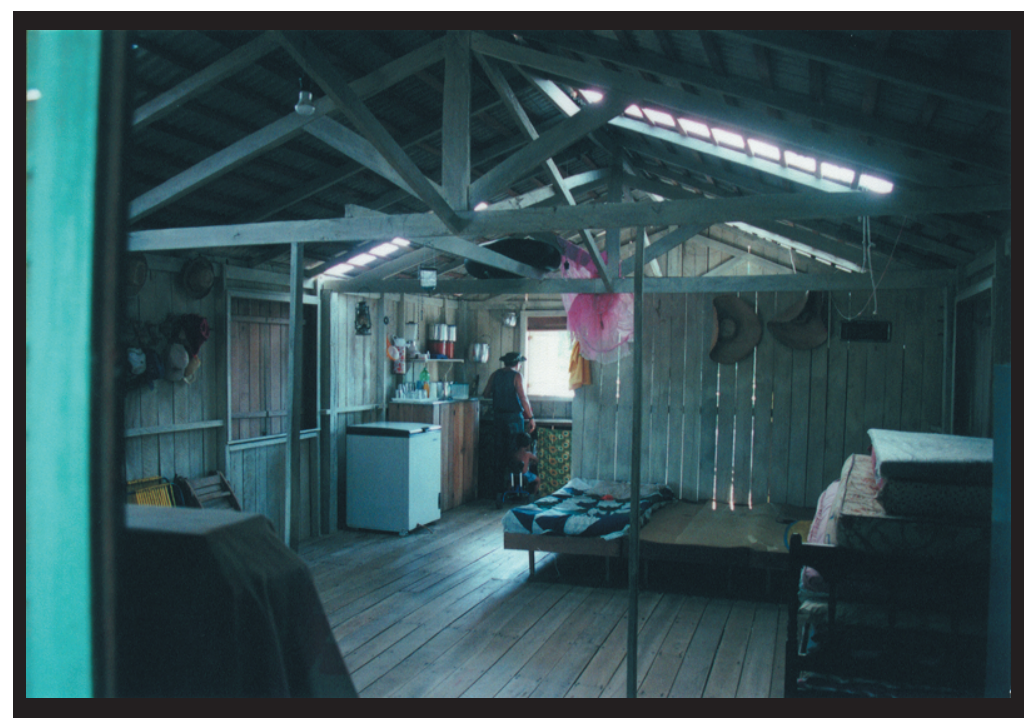

FIGURA 9. Vista Interna da Sede da Fazenda 


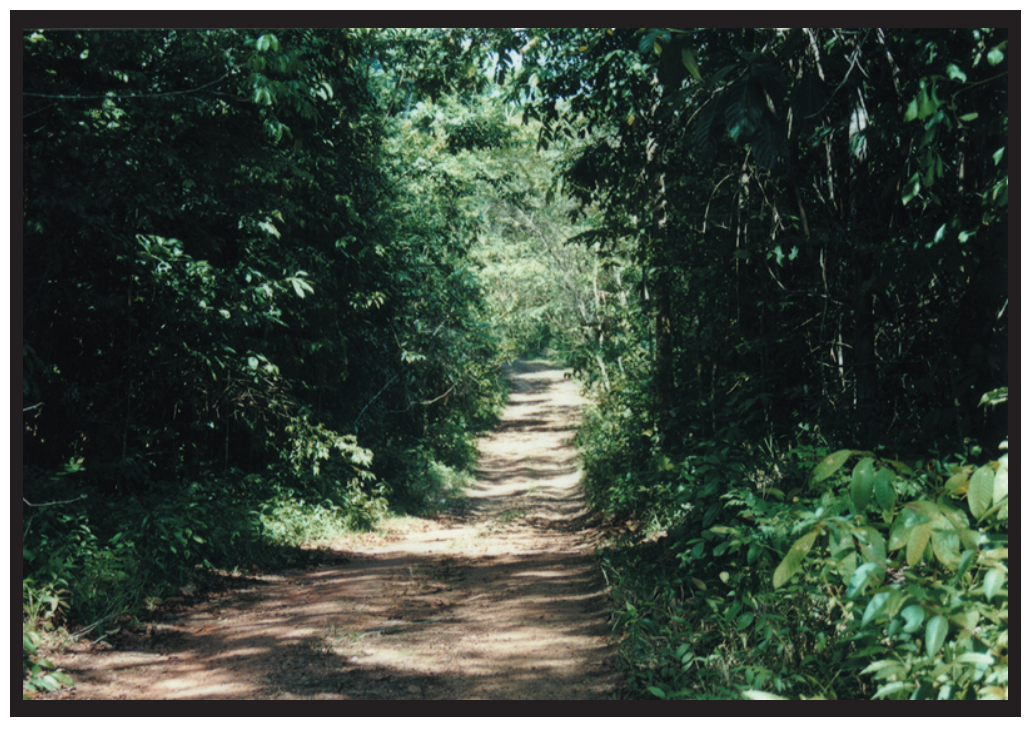

FIGURA 4. Caminho até a sede da Fazenda

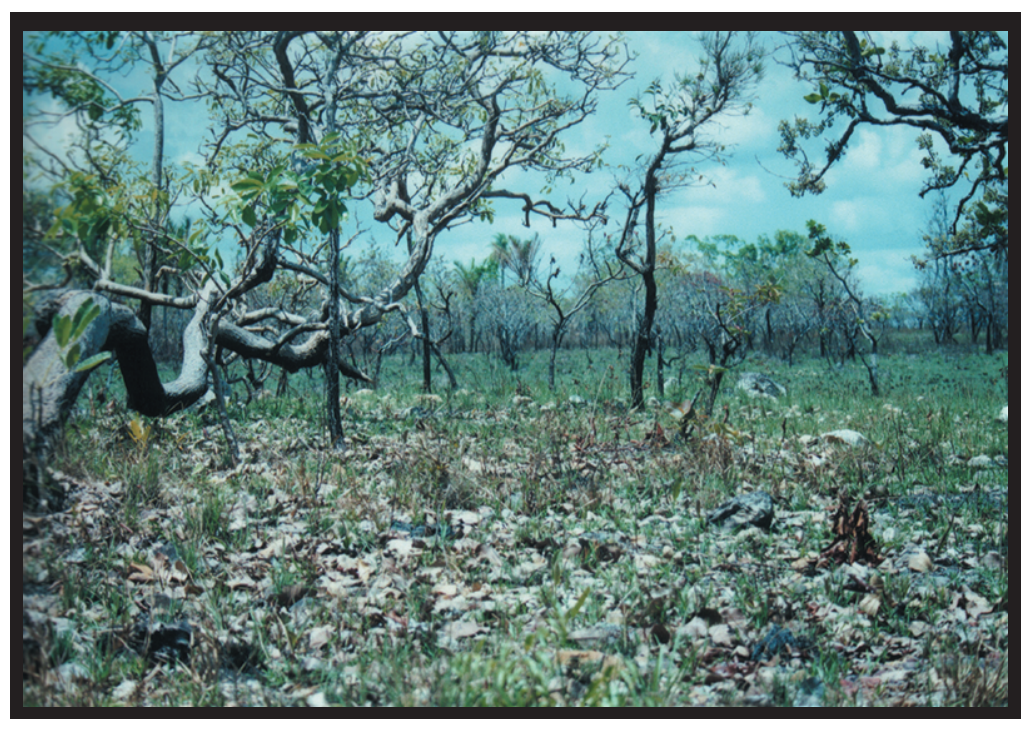

FIGURA 5. Mancha de Cerrado na Fazenda

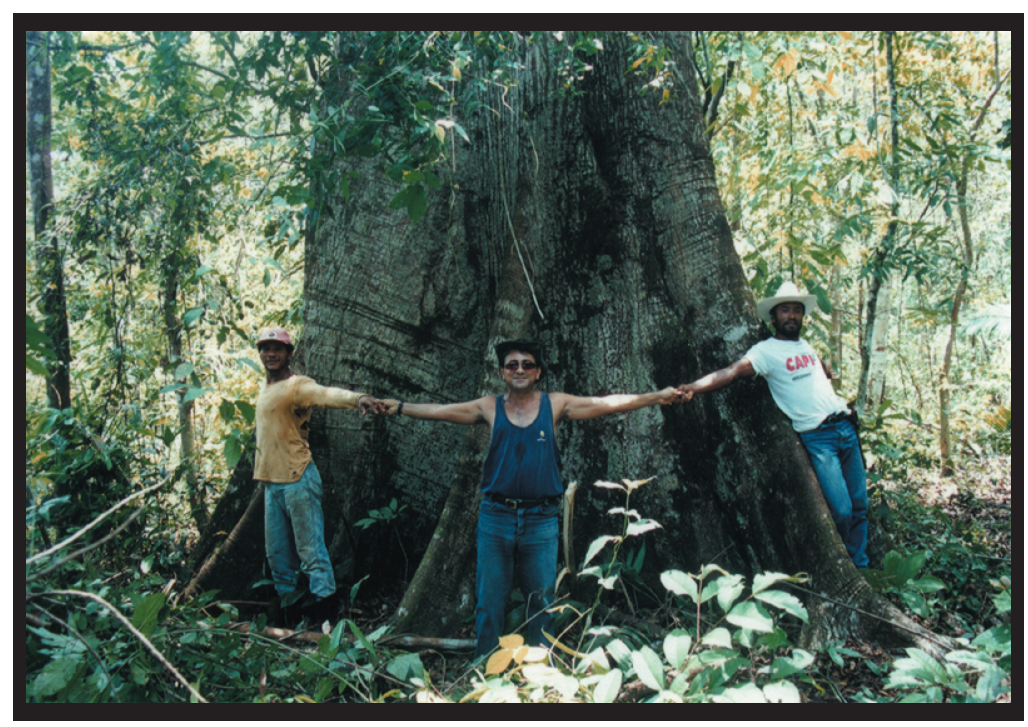

FIGURA 6. O tamanho médio das árvores da propriedade 


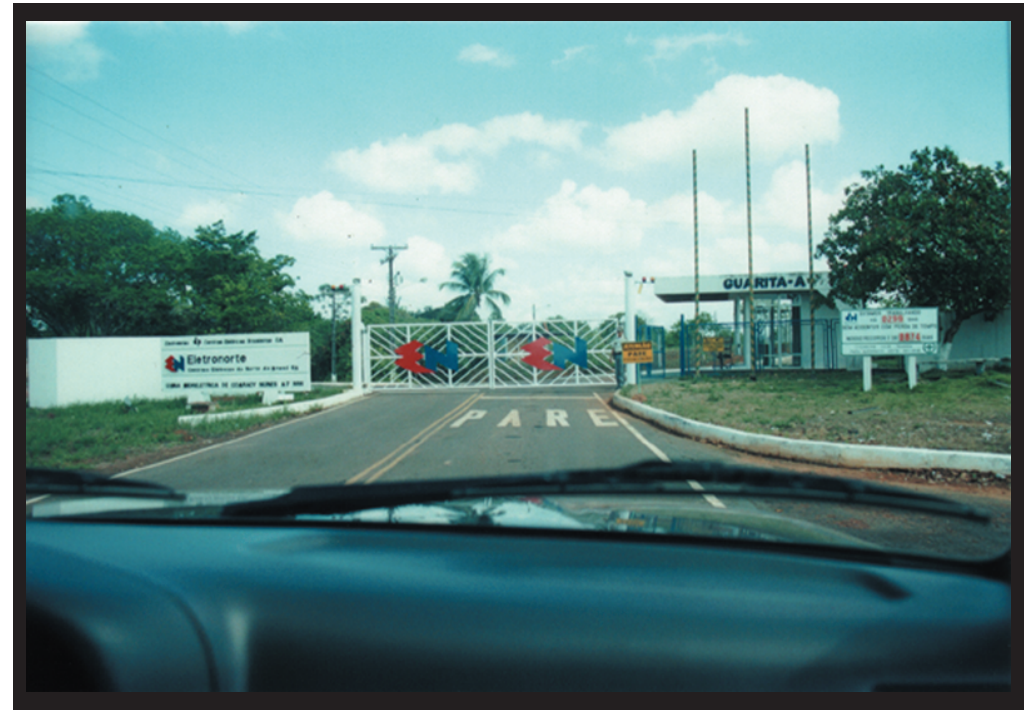

FIGURA 1. Guarita de Entrada pela Eletronorte

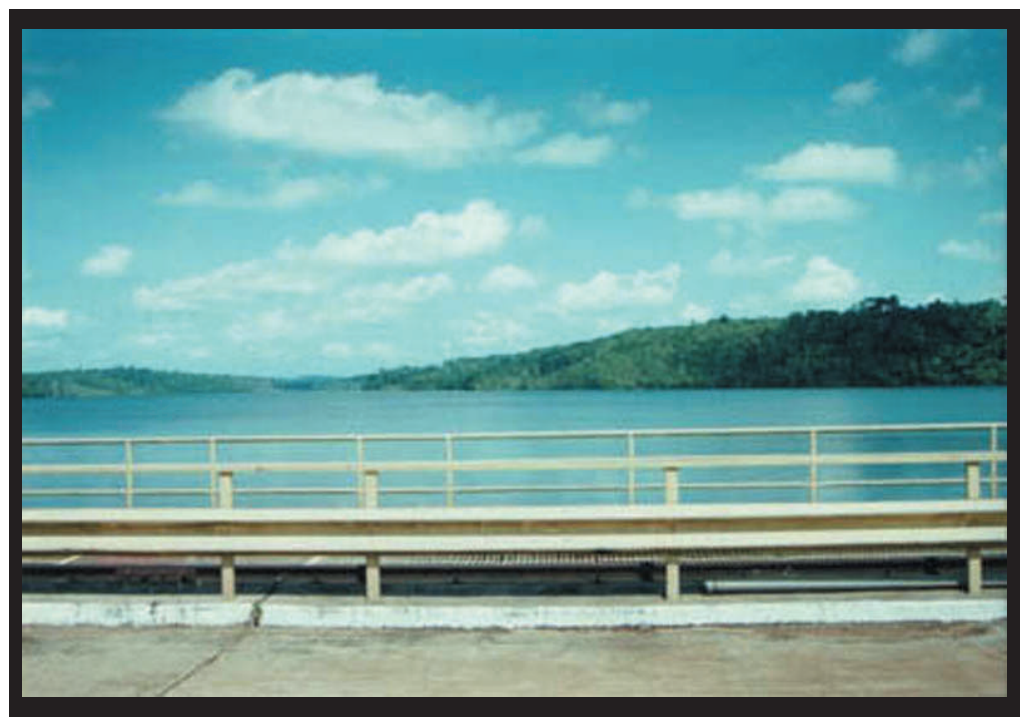

FIGURA 2. Lago da Represa do Paredão e RPPN

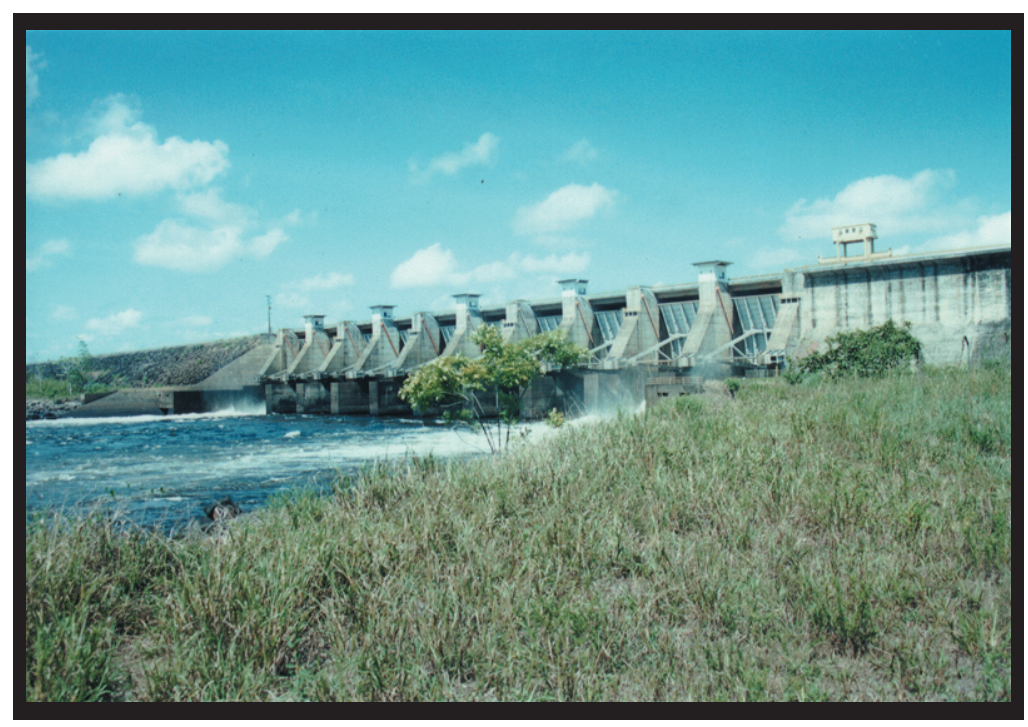

FIGURA 3. Represa do Paredão e Corredeiras 
Mapa de Fotografias

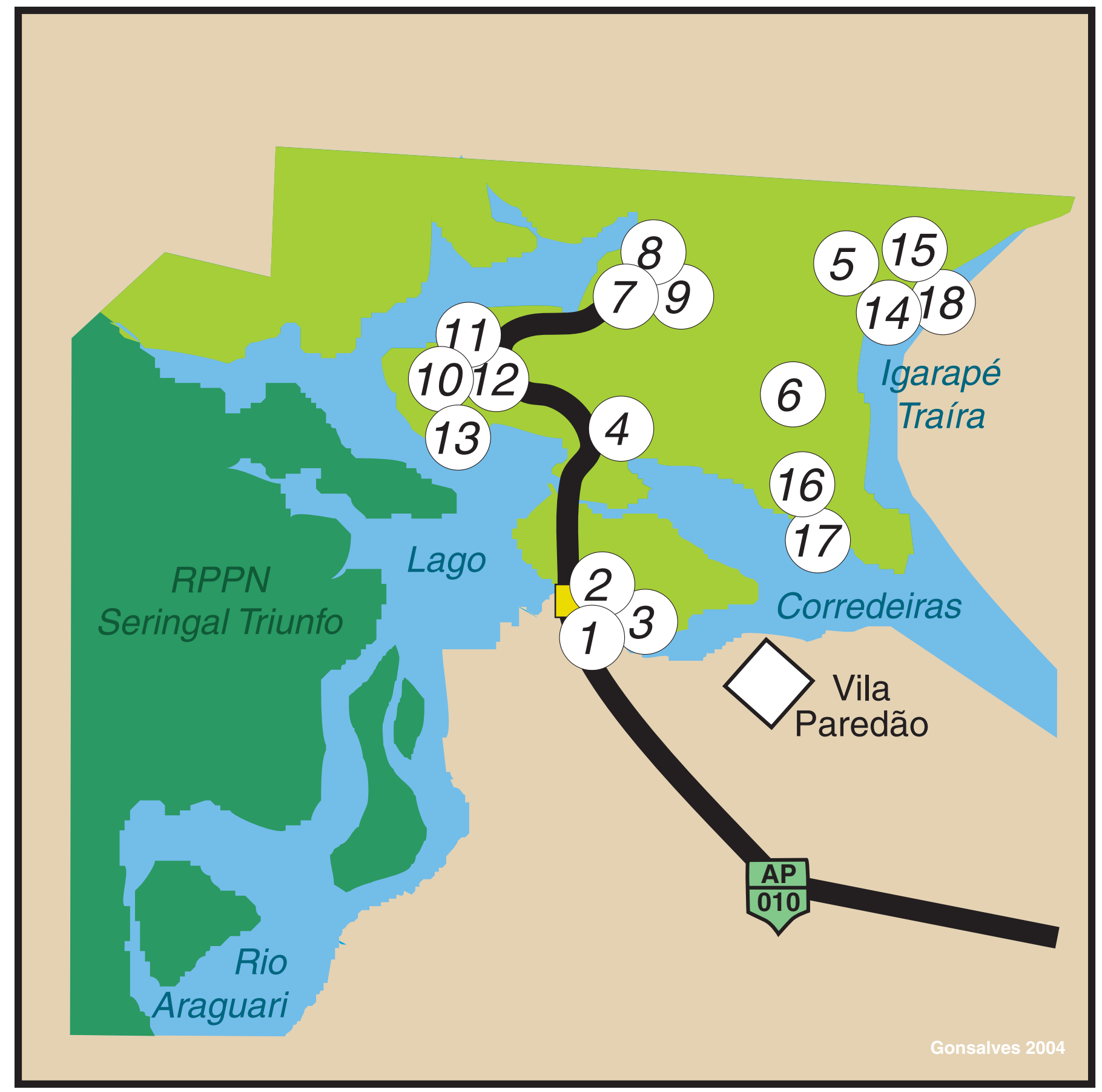

LEGENDA:

USINA HIDROELÉTRICA

DE COARACY NUNES

ZONA DE PROTEÇÃO INTEGRAL

(REPRESA DO PAREDÃO) ELETRONORTE 
Detalhe Fazenda e RPPN

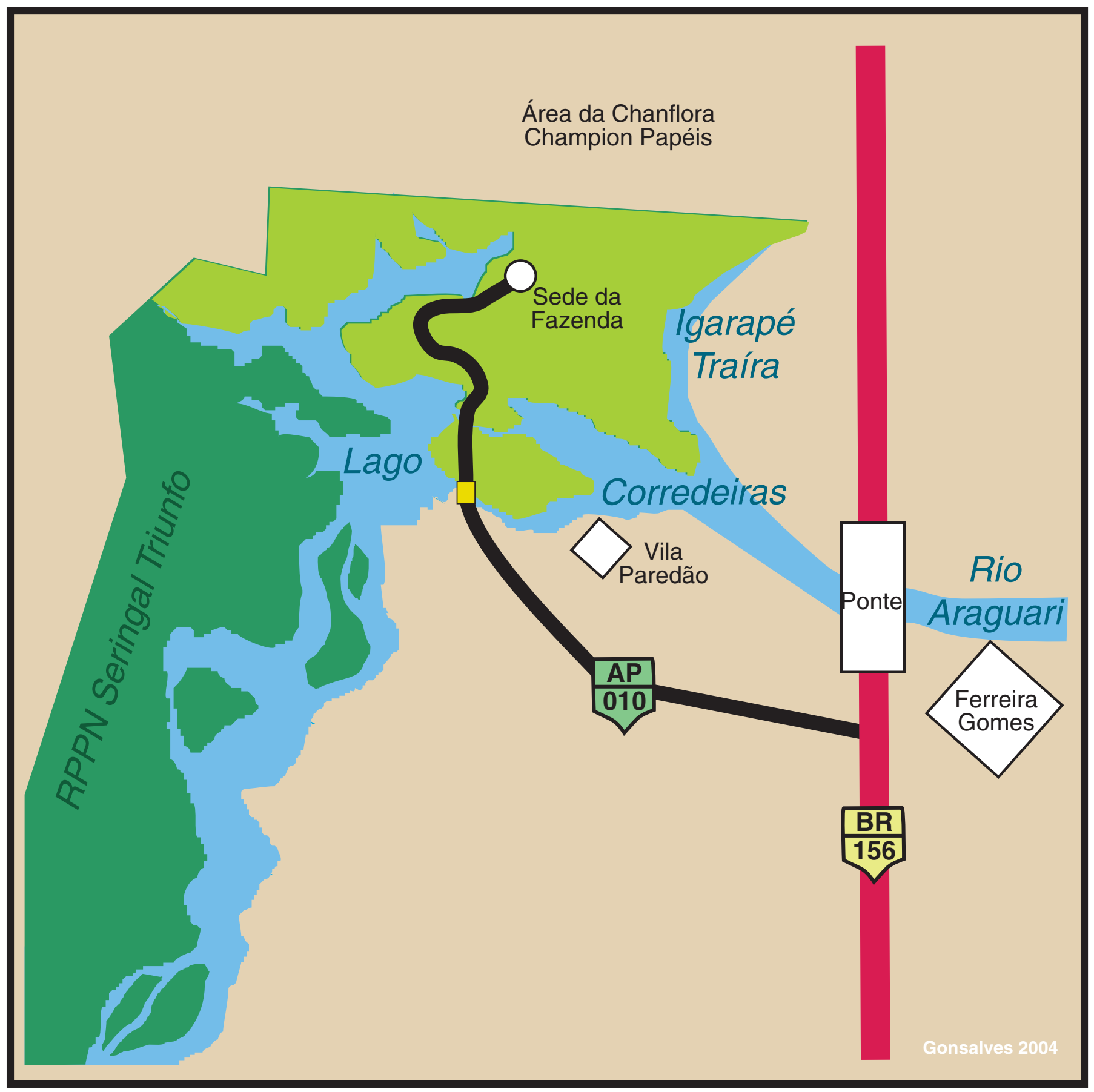

LEGENDA:

USINA HIDROELÉTRICA

DE COARACY NUNES

(REPRESA DO PAREDÃO)

ELETRONORTE
ESTRADA DE ASFALTO

ESTRADA DE TERRA 
Reserva Particular do Patrimônio Natural Seringal Triunfo

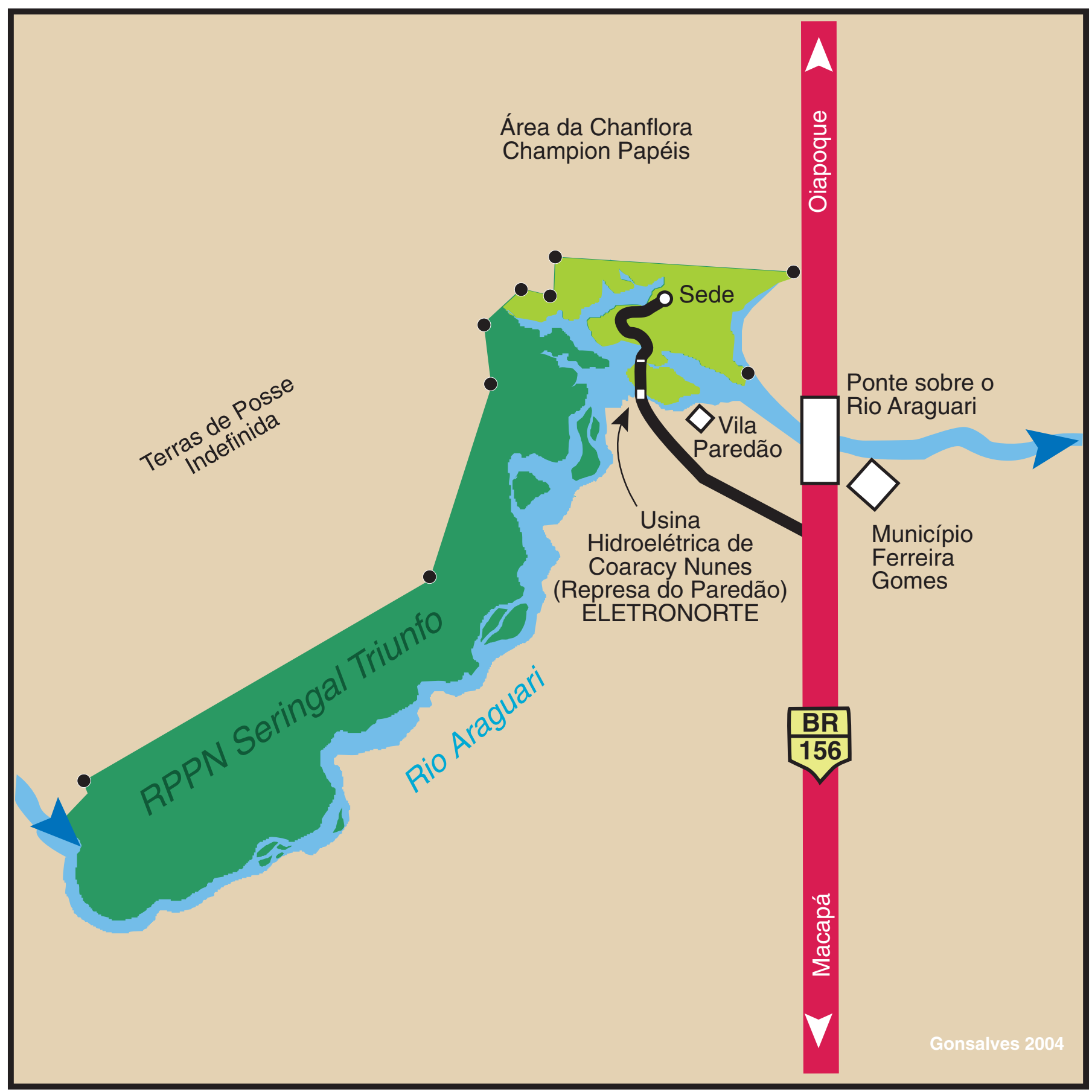

LEGENDA:

FAZENDA

1.800 ha

RESERVA

9.996 ha
RODOVIA DE ACESSO

BR 156

- MARCO TERRITORIAL

DA PROPRIEDADE 
BR 156 Ferreira Gomes

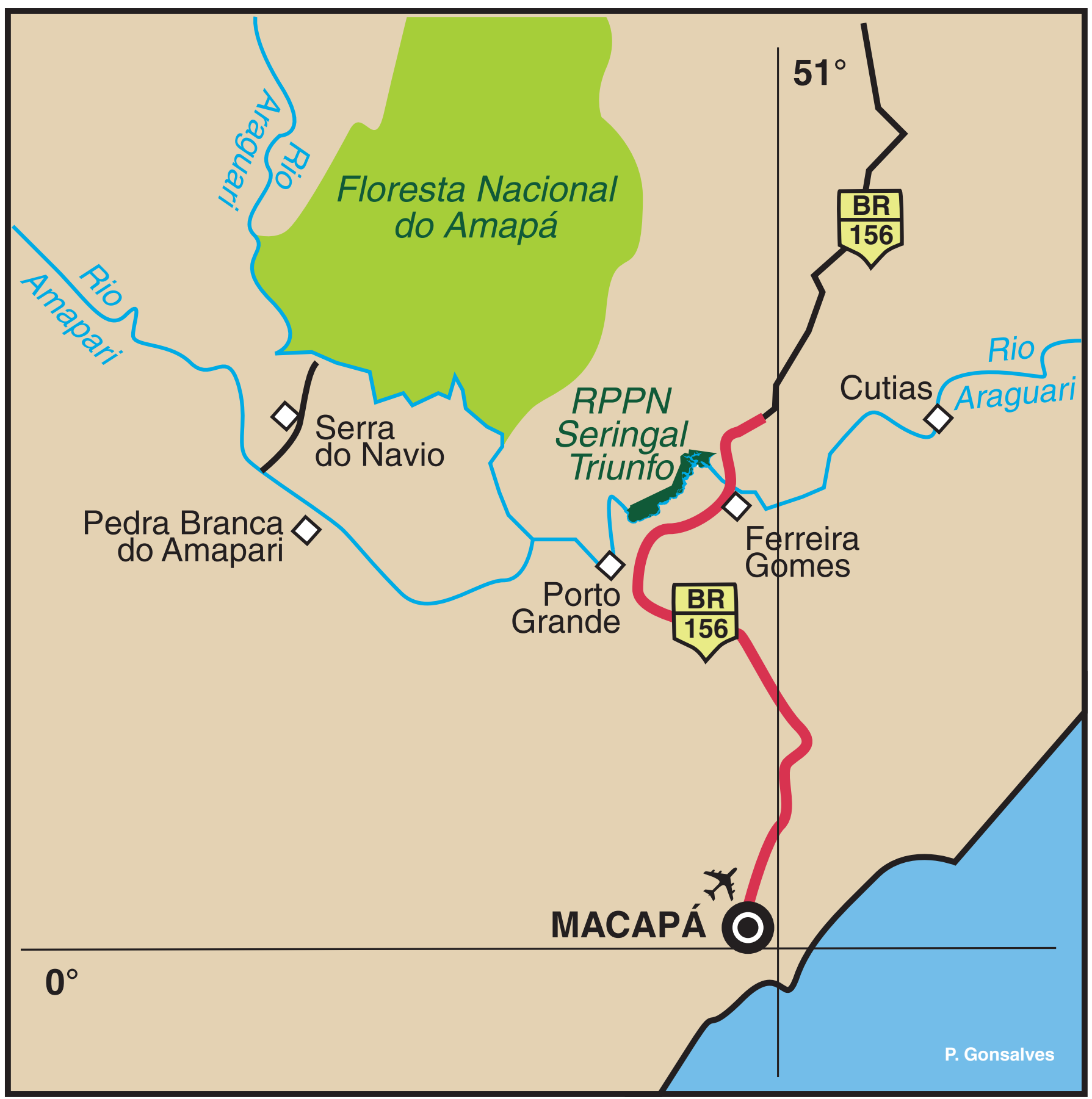

LEGENDA:

FLORESTA NACIONAL DO AMAPÁ

RODOVIA DE ASFALTO

ACESSO BR 156

RESERVA PARTICULAR DO PATRIMÔNIO NATURAL SERINGAL TRIUNFO 
Unidades de Conservação do Amapá

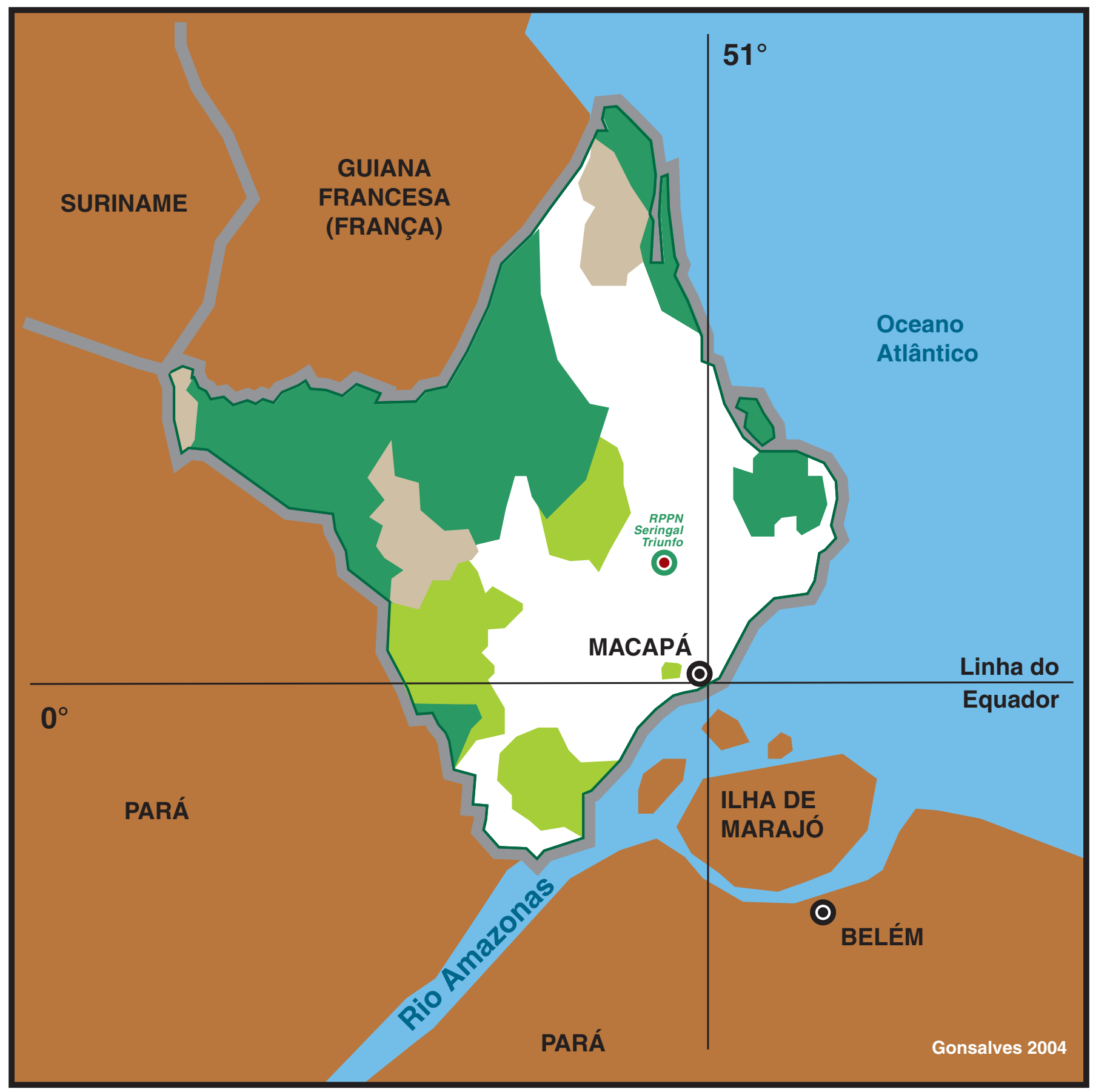

LEGENDA:

RESERVAS FEDERAIS

RESERVAS ESTADUAIS
ÁREAS INDÍGENAS

- RPPN SERINGAL TRIUNFO 


\section{Áquas}

$\square$ Cachoeira $\square$ Lago $\square$ Rio $\quad \square$ Poço $\square$ Córrego $\square$ Mina

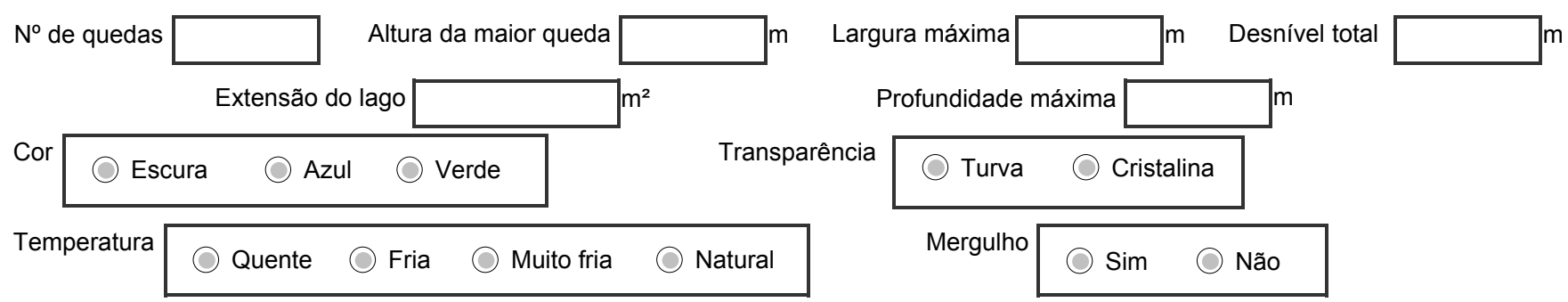

Balneabilidade Ótima Boa Ruim Inexistente

Possibilidade de banho

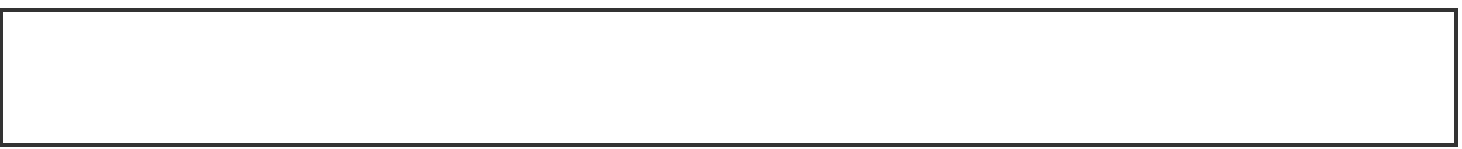

Característica da paisagem

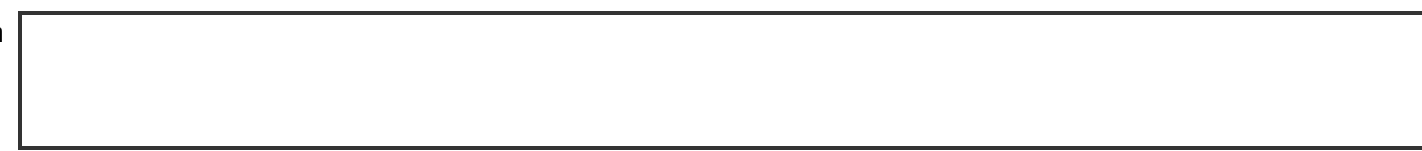

Outras possibilidades recreacionais

Obs

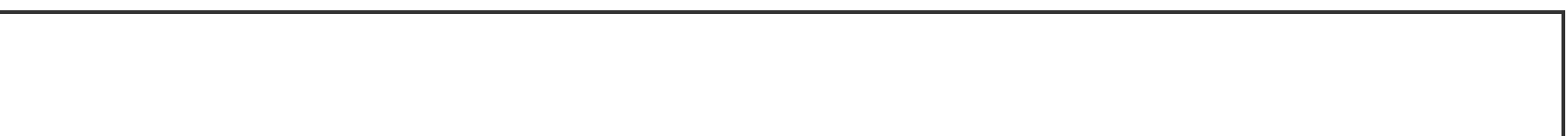

